\title{
New Clicked Full Agonists of the Estrogen Receptor $\boldsymbol{\beta}$
}

\author{
Sebastian Demkowicz, ${ }^{a, b}$ Kamila Filipiak, ${ }^{a, c}$ Maciej Maslyk,${ }^{a, c}$ Jakub Ciepielski, ${ }^{a, d}$ Sonia de Pascual- \\ Teresa, ${ }^{e}$ Sonsoles Martín-Santamaría, ${ }^{a}$ Beatriz de Pascual-Teresa, ${ }^{* a}$ Ana Ramos. ${ }^{* a}$
}

Received (in $X X X, X X X) X t h X X X X X X X X X 20 X X$, Accepted $X$ th $X X X X X X X X X 20 X X$

${ }_{5}$ DOI: 10.1039/b000000x

A click chemistry approach was used to synthesize a series of 1,4-diaryl-substituted 1,2,3-triazoles designed to behave as estrogen receptor ligands. We studied their affinities for both receptors $\alpha$ and $\beta$, their agonist activities in a cell-based luciferase reporter assay and their effect on the proliferation of the hormone dependent MCF-7 cell line. We found two compounds (3a and 3c) that behave as selective full 10 agonists for ER $\beta$ at a $20 \mu \mathrm{M}$ concentration, and one of them (3c) deprived of proliferative effect on MCF7 cells.

\section{Introduction}

The estrogen receptor (ER) is a member of the nuclear receptor ${ }_{15}$ gene family binding the steroid hormone estradiol. ${ }^{1}$ Two subtypes are known of ER, designated ER $\alpha$ and ER $\beta$. Both ER subtypes have overlapping but also unique roles in estrogendependent action and are important targets in pharmaceutical industry. Additionally, ER $\alpha$ and $E R \beta$ have different 20 transcriptional activities in certain ligand, cell-type, and promoter contexts.

The low expression level of ER $\beta$ in reproductive tissues such as uterus, suggests that a selective ER $\beta$ agonist may maintain the 25 beneficial effects of estrogen, without the increased risk of breast and endometrial cancer. A number of selective ligands have been already identified. ${ }^{2}$ ER $\beta$ selective agonist ERB-041 (226-fold selective for $\beta$ ) has been used to demonstrate that this receptor may be a useful target for certain inflammatory processes. ${ }^{3}$ Other 30 nonsteroidal scaffolds which have been developed as ER $\beta$ ligands are diarylpropanenitriles (DPN), ${ }^{4}$ 2-phenylnaphthalenes (WAY202196), ${ }^{2,5}$ and aryll-2H-indazoles. ${ }^{6}$ We have described a series of benzonaphthofuran and naphthothiophene based ligands which behave as ER $\beta$ agonists and ER $\alpha$ antagonists, ${ }^{7}$ and present an 35 interesting antitumor activity against two pancreatic cell lines. ${ }^{8}$ Introduction of a basic side chain in these scaffolds has led to full antagonists of ER $\beta$, with potency in the low micromolar concentration in a cell-based luciferase reporter assay, and completely devoid of activity against the ER $\alpha$ at the same 40 concentration range. ${ }^{9}$

Click chemistry has had a profound effect on the design and development of novel compounds for therapeutic applications. ${ }^{10}$ In particular, the Copper-Catalyzed reaction between an Azide 45 and an Alkyne (CuAAC) has been widely used in fragment-based drug design, and target-guided synthesis (in situ click chemistry). ${ }^{11}$

Tron and coworkers ${ }^{12}$ used CuAAC click chemistry to obtain a so series of 1,4-diaryl-substituted 1,2,3-triazoles 1 (Fig. 1) and evaluated their effect on the proliferation of the hormone dependent MCF-7 cell line. The only active compound promoted proliferation at a $100 \mathrm{pM}$ concentration and possessed the two hydroxy groups in meta position. This compound was capable of ${ }_{55}$ promoting transcriptional activation in HeLa cells expressing higher levels of ER $\beta$ than ER $\alpha$ at low concentrations. These data suggest ER- $\beta$ selectivity, but further studies on the affinity and transcriptional response on both receptors are required to establish the subtype selectivity of this type of compounds.<smiles>C=Cc1cc(O)cc2nc(-c3ccc(O)c(F)c3)oc12</smiles><smiles>N#Cc1cc(-c2ccc(O)c(F)c2)cc2ccc(O)cc12</smiles><smiles>N#Cc1cc2oc3cc(O)ccc3c2c2ccc(O)cc12</smiles><smiles>Oc1ccc(-c2cn(-c3ccc(O)cc3)nn2)cc1</smiles>

benzonaphthofuran (thiophene) based ligands

Fig. 1 Chemical structures of some known ER $\beta$-selective ligands 
In the search of new and selective ligands of both estrogen receptor isoforms, we were interested in the observation of the authors that the introduction of a triazole ring is compatible with binding to the estrogen receptor, and the possibility to apply this 5 efficient synthetic procedure to obtain analogues with additional substituents on the aromatic rings that could favor the interactions with one of the receptor subtypes.

Thus, we have synthesized two series of 1,4-bis(hydroxyphenyl)10 1H-1,2,3-triazoles 2a-f and 3a-f (Fig. 2), where methyl, trifluoromethyl, fluoro, carboxy and methoxycarbonyl groups have been introduced in orto and meta positions of one of the aromatic rings. We have evaluated the ER $\alpha$ and ER $\beta$ binding affinities of the synthesized compounds and studied the 15 transcriptional activation and proliferative activity in MCF-7 breast cancer line of the most interesting of these.

The best binders were compounds $\mathbf{2 a}$ and $\mathbf{3 a}$, showing $\mathrm{IC}_{50}$ of 8.4 and $8.00 \mu \mathrm{M}$, respectively in ER $\alpha$ and lower binding affinity to ER $\beta$. Compound 3a emerged as a full ER $\beta$ agonist at $20 \mu \mathrm{M}$, 20 while its effect on ER $\alpha$ was negligible at the same concentration. This compound stimulated proliferation of MCF-7 cells with maximal proliferation at $10 \mu \mathrm{M}$. Interestingly, analogue 3c behaved as well as a full ER $\beta$ agonist at $20 \mu \mathrm{M}$, but was deprived of proliferative activity.

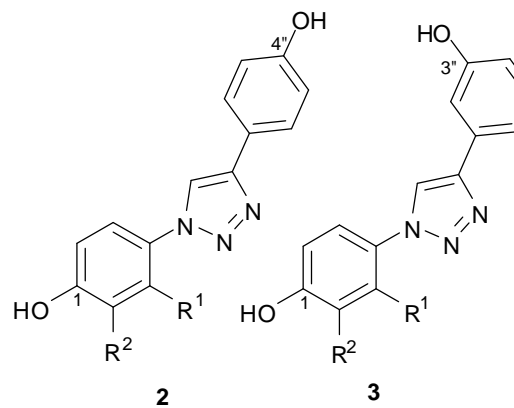

2a, 3a: $\mathrm{R}^{1}=\mathrm{CF}_{3} ; \mathrm{R}^{2}=\mathrm{H}$ 2b, 3b: $R^{1}=H ; R^{2}=F$ 2c, 3c: $\mathrm{R}^{1}=\mathrm{H} ; \mathrm{R}^{2}=\mathrm{CH}_{3}$ 2d, 3d: $\mathrm{R}^{1}=\mathrm{CH}_{3} ; \mathrm{R}^{2}=\mathrm{H}$ 2e, 3e: $R^{1}=\mathrm{COOH} ; \mathrm{R}^{2}=\mathrm{H}$; 2f, 3f: $\mathrm{R}^{1}=\mathrm{H} ; \mathrm{R}^{2}=\mathrm{COOH}$ 2g: $R^{1}=$ COOMe; $R^{2}=H$ 2h, 3h: $R^{1}=H ; R^{2}=$ COOMe

${ }^{25}$ Fig.2 Structure of the synthesized 1,4-diaryl-substituted 1,2,3-triazoles

\section{Results and discussion}

\section{Molecular Modelling}

Preliminary docking studies were carried out in order to assess the capability of the designed compounds to interact with the ligand binding domain (LBD) of both ERs. Several crystallographic structures of the two receptor subtypes in

35 complex with several ligands have been considered: ER $\alpha$ in complex with estradiol (PDB 1A52), raloxifene (PDB 1ERR), genistein (PDB 1X7R), WAY-244 (PDB 1X7E), and 4hydroxytamoxifen (PDB 3ERT), and ER $\beta$ in complex with genistein (PDB 1X7J), THC (PDB 1L2J), WAY-202196 (PDB 40 1YYE), and 4-hydroxytamoxifen (PDB 2FSZ).

All the candidates to be synthesized ( 2 and $\mathbf{3}$ ) were able to bind ERs, at least theoretically.

Regarding predicted binding energies, these were more favourable in the case of ER $\beta$-ligand complexes, as most of the 45 ligands led to values within the highest energy range (from - 7.3 to $-9.5 \mathrm{kcal} / \mathrm{mol}$ ) together with estradiol-like poses. However, in the case of ER $\alpha$, only two compounds, $\mathbf{2 a}$ and $\mathbf{3 a}$, led to the best values in $\operatorname{ER} \alpha(-7.9 \mathrm{kcal} / \mathrm{mol})$, although with different docked poses: 2a presents a pose different to that for estradiol, while $\mathbf{3 a}$ 50 establishes interactions similar to those found for estradiol, as will be discussed below.

Regarding the binding mode, the analysis of the docking studies showed that all compounds could adopt estradiol-like poses in $E R \beta$, while in ER $\alpha$ no estradiol-like poses were found or they did 55 not show proper binding. Compounds $\mathbf{3 a}$ and $\mathbf{3 d}$, were an exception, because they were the only ligands exhibiting estradiol-like poses when docked inside ER $\alpha$ (predicted binding energies of -7.9 and $-6.8 \mathrm{kcal} / \mathrm{mol}$, respectively).

Overall, these results may point to a preference for ER $\beta$ binding, 60 with the exception of compounds $\mathbf{2 a}$ and $\mathbf{3 a}$, which may present binding abilities for both receptors.

When studying ligand-receptor interactions at atomic detail, it can be observed that compound 3a establishes hydrogen bonds between the OH-1 group and Glu305-Arg346, and the OH-3', ${ }_{65}$ group with His475 (ER $\beta$ numbering), in an estradiol-like fashion in both ER subtypes. Additionally, the $\mathrm{CF}_{3}$ group is hosted in a hydrophobic cavity delimited by Leu339, Met340, Leu343, and Leu380 (in ERo: Leu387, Met388, Leu391, and Leu428). In the case of 3d, which also establishes estradiol-like binding modes in 70 both receptors, the presence of the $\mathrm{CH}_{3}$ group in this position led to a decrease of $1.1 \mathrm{kcal} / \mathrm{mol}$ in the docked binding energy, indicating the role of the $\mathrm{CF}_{3}$ group in the binding (see ESI). The $\mathrm{CF}_{3}$ group is also present in 2a. In $\mathrm{ER} \beta$, docking studies for this compound led to an estradiol-like binding pose with the opposite 75 orientation to that found for 3a. So, hydrogen bonds were identified between $\mathrm{OH}-1$ and His-475; and between $\mathrm{OH}-4$ "' and Glu305-Arg346. The $\mathrm{CF}_{3}$ is accommodated in the vicinity to the previously mentioned hydrophobic cavity, contacting Leu380, Ile376, and Phe377 side chains (Fig. 3). In the case of ER $\alpha$, this 80 compound is predicted to bind in a non estradiol-like pose. These results suggest that the presence of a lipophilic $\mathrm{R}^{1}$ group could favour the binding by the establishment of hydrophobic interactions with the cavity delimited by Leu339, Met340, Leu343, Ile376, Leu380 and Phe377 side chains (ER $\beta$ 85 numbering), and that scaffold $\mathbf{3}$ is more suitable for anchoring the receptor (specially ER $\beta$ ).

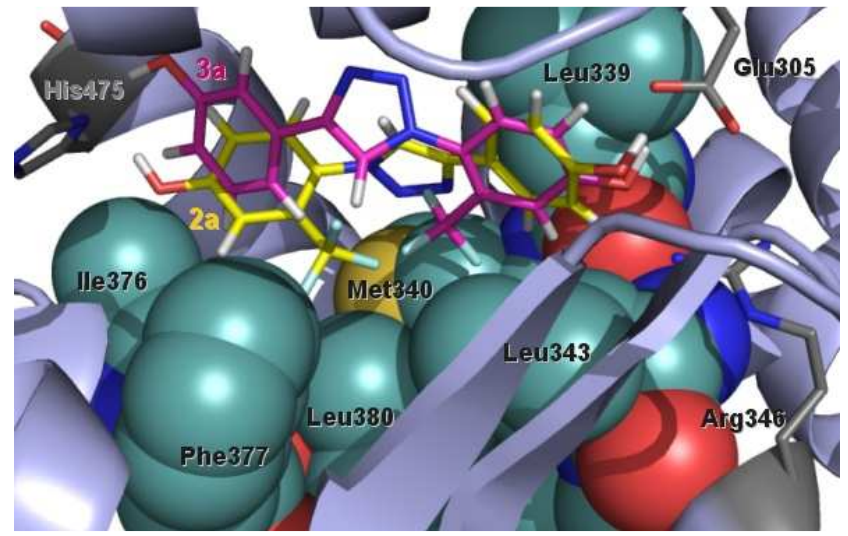

90 Fig. 3 Docked binding modes obtained for compounds $\mathbf{2 a}$ and 3a in ER $\beta$.

\section{Chemistry}

As a result of the previous theoretical study, we decided to synthesize compounds $\mathbf{2}$ and $\mathbf{3}$. The detailed synthesis of the azide fragment is shown in Scheme 1. Some of the amines used 

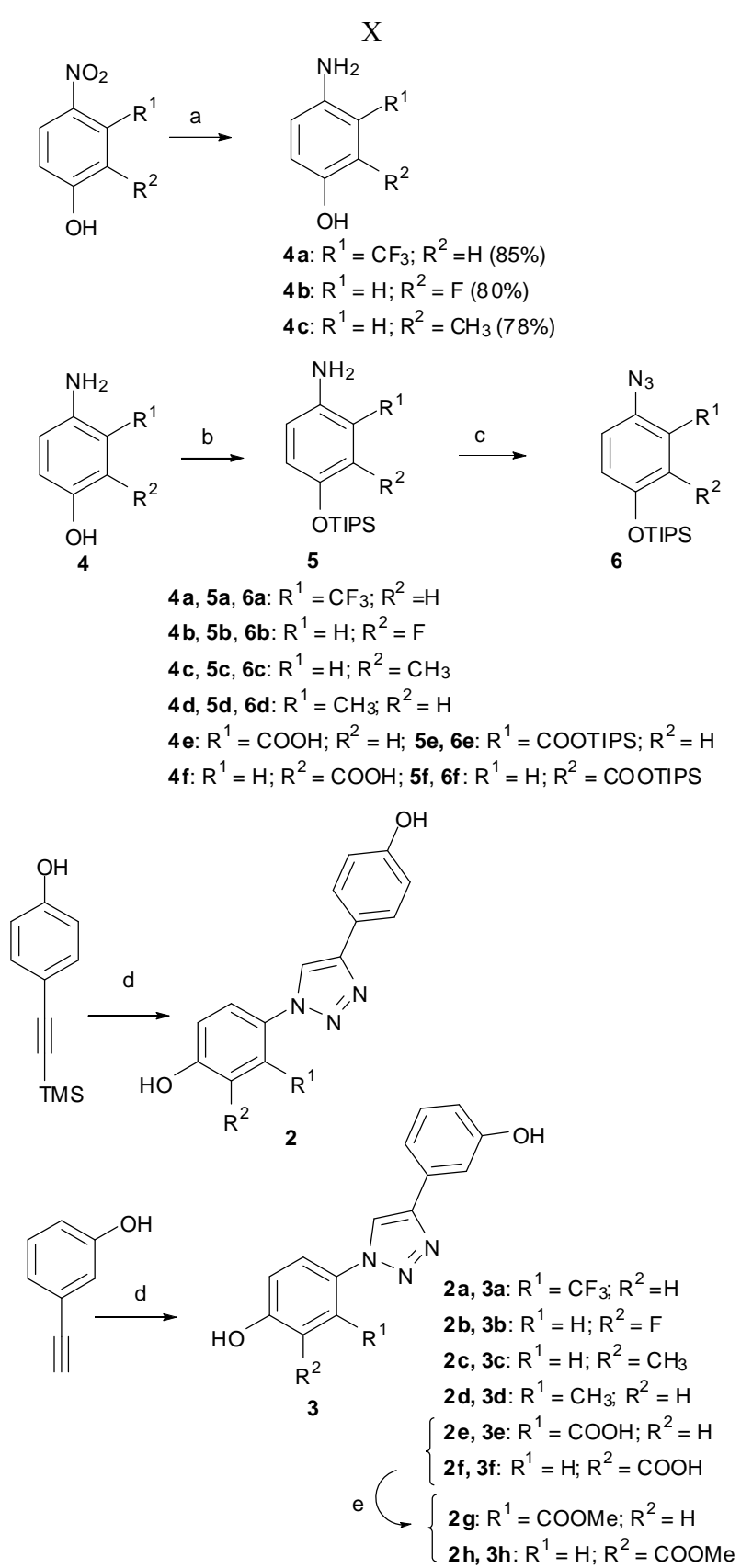

Scheme 1. Synthesis of ligands 2 and 3. (a) $\mathrm{H}_{2}, \mathrm{Pd} / \mathrm{C}$ for $\mathbf{4 a}, \mathrm{Sn} / \mathrm{HCl}$ for $4 \mathbf{b}$ and $\mathbf{4 c}$; b) 1 eq. TIPSCl/Et ${ }_{3} \mathrm{~N}$ for $\mathbf{5 a - d}, 2$ eq. TIPSCl$/ \mathrm{Et}_{3} \mathrm{~N}$ for $\mathbf{5 e - f}$; (c) 5 t-BuONO/TMSN 3 ; (d) TBFA, $\mathrm{CuSO}_{4} .5 \mathrm{H}_{2} \mathrm{O}$, sodium ascorbate, DMF; (f) $\mathrm{MeOH}, \mathrm{H}_{2} \mathrm{SO}_{4}$.

(4d-f) are commercially available, and some had to be synthesized (4a-c) by $\mathrm{Sn} / \mathrm{HCl}$ reduction of the corresponding nitrocompounds. After protection of the hydroxyl group (together 10 with the carboxylic groups in the case of $\mathbf{4 e}$ and $\mathbf{4 f}$ ), the TIPSprotected derivatives were transformed into azides $\mathbf{6}$ by reaction with tert-butyl nitrite and azidotrimethylsilane.

These azides were coupled to 3-ethynylphenol and 4((trimethylsilyl)ethynyl)phenol. The former is commercially 15 available, and the latter was obtained by Sonogashira coupling between the commercially available 4-iodophenol and trimethylsilyl acetylene.

For the $\mathrm{CuAAC}$ reaction, we used $\mathrm{CuSO}_{4}(0.1$ eq.) and ascorbic acid $(0.2 \mathrm{eq})$ in the presence of tetrabutylammonium fluoride to 20 bring about the deprotection of 4-((trimethylsilyl)ethynyl)phenol in the reaction mixture and the deprotection of the final triazoles. We have chosen this synthetic pathway, involving the use of protective groups, because, in our first attempt to carry out the click reaction starting from unprotected azides, we observed a 25 low solubility of the reactants in the reaction medium, and the formation of a complex mixture of compounds by TLC and ${ }^{1} \mathrm{H}-$ NMR analysis of the crude reaction.

Finally, acids $\mathbf{2 e , f}$ and $\mathbf{3 f}$ were transformed into the corresponding methyl esters $\mathbf{2} \mathbf{g}, \mathbf{h}$ and $\mathbf{3 h}$ by reaction with $\mathrm{MeOH}$ 30 in the presence of $\mathrm{H}_{2} \mathrm{SO}_{4}$.

\section{Estrogen Receptor Binding Assays.}

The affinity for ER $\alpha$ and ER $\beta$ of compounds 2 and $\mathbf{3}$ were determined in an in vitro competitive binding assay, following a 35 reported method, ${ }^{13}$ with some modifications. All compounds were tested at $10 \mu \mathrm{M}$ and only compounds $2 \mathbf{a}, 2 \mathbf{2 e}, \mathbf{3 a}$ and $\mathbf{3 d}$ presented enough affinity at this concentration to determine the $\mathrm{IC}_{50}$ at least in one of the receptors. Table 1 shows a summary of the results.

40 Table 1 Affinities ${ }^{\mathrm{a}}$ of compounds $\mathbf{2}$ and $\mathbf{3}\left(\mathrm{IC}_{50}\right)$ and $\%$ of $\left[{ }^{3} \mathrm{H}\right]$-estradiol binding to $\mathrm{ER} \alpha$ and $\beta$ at $10 \mu \mathrm{M}$.

\begin{tabular}{cccccc}
\hline & & & & & \\
ligand & $\mathrm{IC}_{50}$ & $\mathrm{IC}_{50}$ & & $10 \mu \mathrm{M}$ & $10 \mu \mathrm{M}$ \\
& $\mathrm{ER} \alpha$ & $\mathrm{ER} \beta$ & $\beta / \alpha$ ratio & $\mathrm{ER} \alpha$ & $\mathrm{ER} \beta$ \\
\hline $\mathbf{2 a}$ & 8.4 & 22.6 & 2.6 & 47 & 75.3 \\
$\mathbf{2 b}$ & $\mathrm{NA}$ & $\mathrm{NA}$ & - & 98.5 & 100 \\
$\mathbf{2 c}$ & $\mathrm{NA}$ & $\mathrm{NA}$ & - & 100 & 100 \\
$\mathbf{2 d}$ & $\mathrm{NA}$ & $\mathrm{NA}$ & - & 76.9 & 87.3 \\
$\mathbf{2 e}$ & 14.5 & 130.0 & 8.9 & 60.9 & 79.7 \\
$\mathbf{2 f}$ & $\mathrm{NA}$ & $\mathrm{NA}$ & - & 94.8 & 100 \\
$\mathbf{2 g}$ & $\mathrm{NA}$ & $\mathrm{NA}$ & - & 83.9 & 94.4 \\
$\mathbf{2 h}$ & $\mathrm{NA}$ & $\mathrm{NA}$ & - & 98.6 & 100 \\
$\mathbf{3 a}$ & 8.00 & $>100$ & & 50.7 & 100 \\
$\mathbf{3 b}$ & NA & NA & - & 100 & 100 \\
$\mathbf{3 c}$ & NA & NA & - & 100 & 100 \\
$\mathbf{3 d}$ & 61.4 & $>100$ & - & 72.5 & 100 \\
$\mathbf{3 e}$ & NA & NA & - & 100 & 100 \\
$\mathbf{3 f}$ & NA & NA & - & 97.8 & 100 \\
$\mathbf{3 h}$ & NA & NA & - & 78.3 & 100 \\
\hline
\end{tabular}

${ }^{a}$ Values are an average of at least 2 experiments with typical standard errors below $15 \%$. NA -not achieved

${ }^{b}$ The percentage of specific binding of $[2,4,6,7,16,17-3 \mathrm{H}]$-estradiol to ER.

45

Transcription Assays.

To characterize the agonist/antagonist profile we first submitted three compounds $(\mathbf{2} \mathbf{a}, \mathbf{2} \mathbf{e}$, and $\mathbf{3 a}$ ) with the highest binding affinity.

${ }_{50}$ They were assayed for transcriptional activity through both receptor subtypes, with estradiol as a reference. Reporter gene assays were conducted in mammalian cells containing either ER $\alpha$ or ER $\beta$-responsive luciferase reporter gene. The luciferase gene expression appears when ligand-bound ER undergoes nuclear 55 translocation, DNA binding, assembling of the co-activators and other factors which are necessary to obtain a functional 
transcription complex, in which target gene is expressed. The readout from those reporter cells fulfils similar interaction demands to those which can be observed in vivo. In the reporter gene assays on cells treated with saturating concentrations of 5 estradiol, ER $\beta$ showed a maximal activity which was $62 \%$ lower than the maximal activity observed on ER $\alpha$. This observation is in agreement with previous published results. ${ }^{14}$

Compounds 2a and 3a showed agonistic effects in ER $\beta$ (Fig. 4).

10 Thus, compound 2a induced a significant increase in luciferase activity $(414 \pm 8,46 \%$ of control) at $10 \mu \mathrm{M}$, and compound $\mathbf{3 a}$ showed a very high efficacy at $20 \mu \mathrm{M}(633 \pm 67,8$ of control), which is comparable to the maximum response of estradiol $(694,38 \pm 6,21$ of control at $4 \mathrm{nM})$. Compound $2 \mathrm{e}$ induced some 15 increase in transcriptional activity but it was not concentrationdependent.

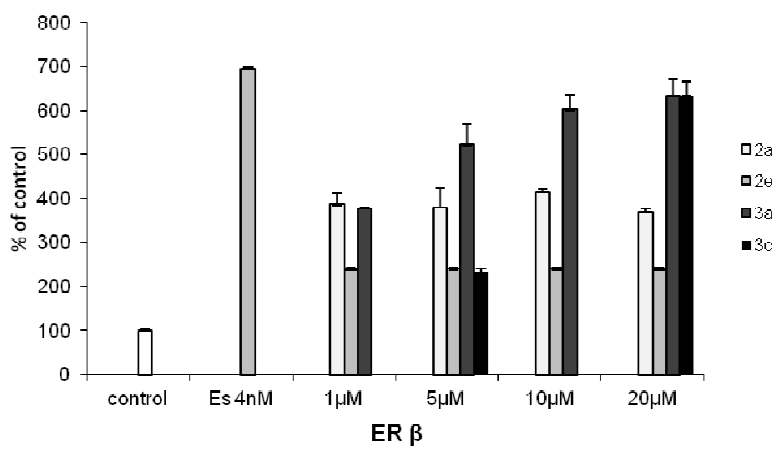

Fig. 4 Transcriptional activation of ER $\beta$ by estradiol $(4 \mathrm{nM})$ and compounds: $2 \mathbf{a}, \mathbf{2 e}, \mathbf{3 a}$ and $\mathbf{3 c}$.

In the case of ER $\alpha$ (Fig. 5), compound $2 \mathbf{a}$ was able to activate the receptor with the maximum activity at $20 \mu \mathrm{M}(859,56 \%$ of control) in comparison to the maximum response of estradiol in this receptor $(1689,06 \pm 74,17$ at $100 \mathrm{nM})$. These results suggest 25 that 2a behaves as an agonist for both receptors with similar efficacy.

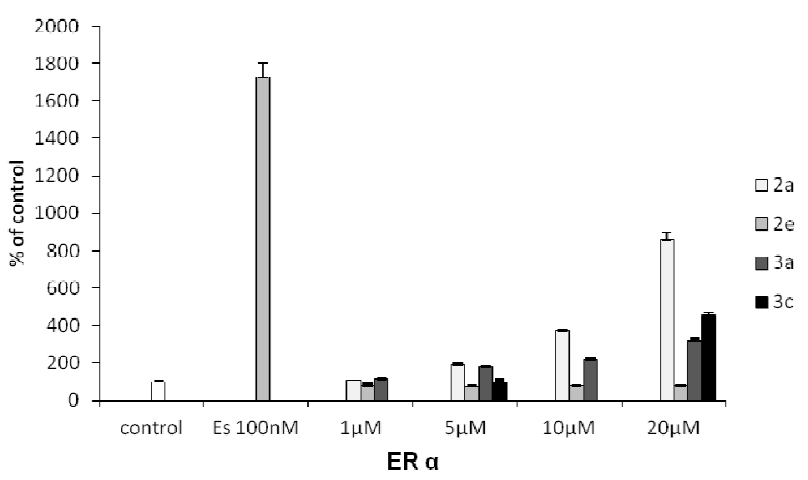

Fig. 5 Transcriptional activation of ER $\alpha$ by estradiol $(100 \mathrm{nM})$ and compounds $\mathbf{2 a}, \mathbf{2 e}, \mathbf{3 a}$ and $\mathbf{3 c}$

More interestingly, only a slight activity on ER $\alpha$ was observed in the case of compound 3a at $20 \mu \mathrm{M}(320,42 \pm 14,74$ of control in comparison to $1689,06 \pm 74,17$ for $100 \mathrm{nM}$ of estradiol. This result
40 demonstrates that $\mathbf{3 a}$ is selective in its transcriptional activity, behaving as a full agonist for ER $\beta$ at $20 \mu \mathrm{M}$, while being a weak agonist for $E R \alpha$ at the same concentration. It is of great interest to detect non-steroidal molecules that display agonistic or antagonistic properties on the ERs in a specific manner.

It should be noted that there is no correlation between binding affinity and transcriptional potency for this compound. This lack of correlation has been observed in other cases, ${ }^{15}$ and could be explained by differences in the mode of binding between the 50 ligands, the ERs and various cellular coregulators, which could modulate the final ligand response in the transcriptional assay.

Finally, no transcriptional effect was present on ER $\alpha$ at the tested concentrations in the case of $\mathbf{2 e}$. This compound could be classified as a selective partial agonist of ER $\beta$. No antagonistic activity was observed for all tested compounds.

Effect on the proliferation of a MCF-7 breast cancer cell line. We determined the proliferative activity of all the synthesized compounds on the hormone dependent MCF-7 breast cancer line (Fig. 6 and Fig. 7).

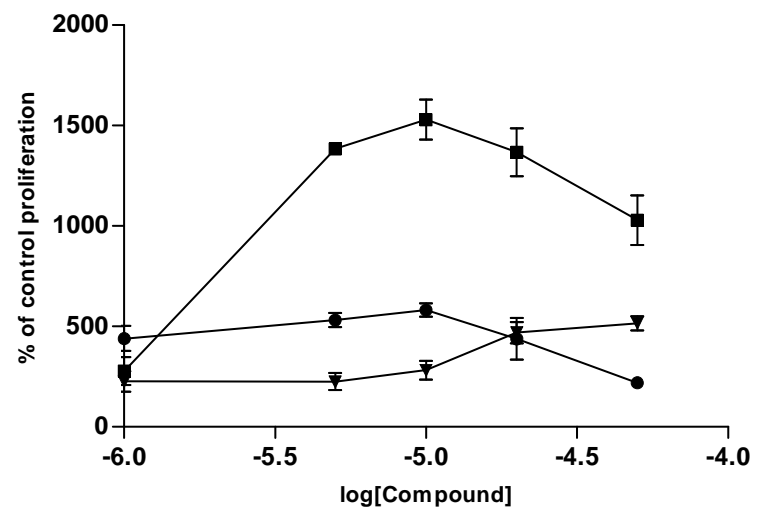

Fig.6 Concentration response curves of proliferation of MCF-7 treated with the following compounds: $\mathbf{2 a}(\bullet), \mathbf{2 e}(\boldsymbol{\nabla})$, and $\mathbf{3 a}(\mathbf{\square})$, evaluated with 65 crystal violet assay. Data are mean $\pm \mathrm{SD}$ of at least 5 determinants in 2 independent experiments.

${ }_{70}$ Compound 3a induced an increase in proliferation, displaying a bell-shape dose response curve, with maximal proliferation at 10 $\mu \mathrm{M}(1529,15 \% \pm 99,6)$ of solvent control in comparison to $446,17 \% \pm 45,4$ obtained for $1 \mathrm{pM}$ estradiol. The other two ER binders $\mathbf{2 a}$ and $\mathbf{2 e}$ also increased proliferation but with lower 75 efficacy with maximum at $10 \mu \mathrm{M}(581,59 \pm 33,12)$ and $50 \mu \mathrm{M}$ $(483,35 \pm 39,81)$ for $\mathbf{2 a}$ and $\mathbf{2 e}$, respectively.

This proliferative activity could be explained by its effect on the ER pathway, as we proved that these compounds behave as ER 75 agonists.

The rest of compounds presented different profiles that did not 80 correlate with their binding affinities (Fig. 7). Interestingly compound 3c did not induce proliferation of MCF7 cells, what is in agreement with its lack of affinity for both receptors in the binding assay. However, taking into account the observed lack of correlation between the binding affinity and the functional 
activity of the previously studied compounds (2a, 2e and 3a), we decided to study its transcriptional activation capability (Fig. 4 and Fig. 5). We found that $3 \mathbf{c}$ behaved as a full agonist at $20 \mu \mathrm{M}$, increasing luciferase activity $(634,1 \pm 30,8$ of control) in a similar 5 extent than estradiol at $4 \mathrm{nM}(694,38 \pm 6,21)$, while its activation of ER $\alpha(455,2 \pm 14,2$ of control) was only $27 \%$ of control activity of estradiol (1689,06 $\pm 74,17$ at $100 \mathrm{nM})$ (Fig. 4 and Fig. 5)

Thus, 3c is a full ER $\beta$ agonist, without promoting the proliferation of MCF-7 cells, a biological profile which holds 10 promise for the treatment of inflammatory diseases including rheumatoid arthritis, and cardiovascular and CNS conditions. ${ }^{14}$

a)

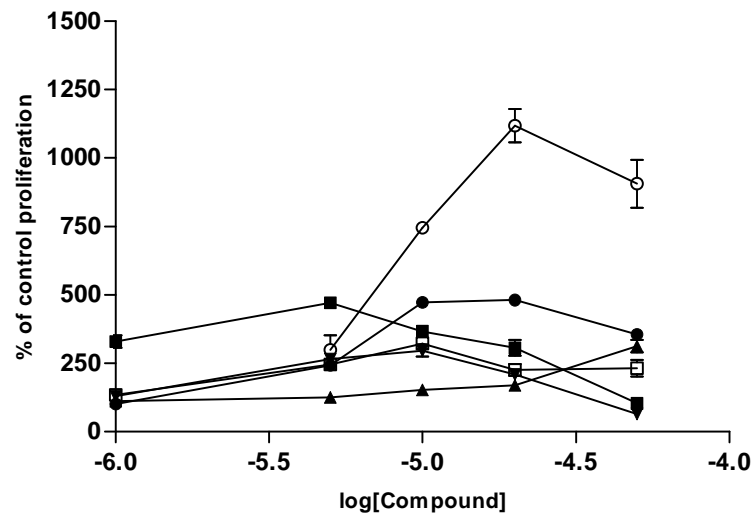

b)

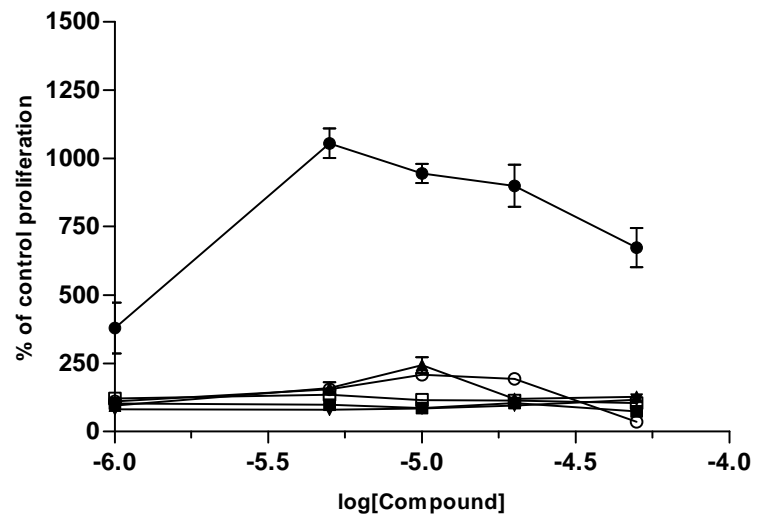

Fig.7 Concentration response curves of proliferation of MCF-7 treated with the following compounds: a) $2 \mathbf{b}(\bullet), \mathbf{2 c}(\mathbf{\nabla}), \mathbf{2 d}(\mathbf{\bullet}), \mathbf{2 f}(\mathbf{\Delta}), \mathbf{2 g}(\circ)$, $20 \mathbf{2 h}(\square)$ and b) $3 \mathbf{b}(\circ), 3 \mathbf{c}(\bullet), 3 \mathbf{d}(\bullet), 3 \mathbf{e}(\mathbf{\nabla}), \mathbf{3 f}(\mathbf{\Delta}), 3 \mathbf{h}(\square)$. Data are mean $\pm \mathrm{SD}$ of at least 5 determinants in 2 independent experiments.

\section{Conclusions}

A series of clicked $1 H-1.2 .3$-triazoles have been synthesized, and their affinity and transcriptional activation of both ER $\alpha$ and ER $\beta$

25 have been determined by means of in vitro assays. This study has allowed us to detect two compounds (3a and 3c) that behave as selective full agonists for ER $\beta$ at $20 \mu \mathrm{M}$, while its effect on ER $\alpha$ is considerably lower at the same concentration. These compounds could be useful to gain knowledge on the
${ }_{30}$ physiological role of ER $\beta$. While 3a induced the proliferation of MCF-7 cells, its analogue 3c was completely inactive in this breast cancer cell line. This compound constitutes therefore, a new and promising candidate for the development of ER binding agents useful for the treatment of inflammatory, cardiovascular 35 and CNS diseases, without promoting undesired proliferative effects on breast.

\section{Experimental}

General Methods. Melting points (uncorrected) were determined on a Stuart Scientific SMP3 apparatus. Infrared (IR) spectra were recorded with a Perkin-Elmer 1330 infrared spectrophotometer. ${ }^{1} \mathrm{H}$ and ${ }^{13} \mathrm{C}$ NMR were recorded on a Bruker $300-\mathrm{AC}$ instrument.

${ }_{45}$ Chemical shifts $(\delta)$ are expressed in parts per million; coupling constants $(J)$ are in Hertz. Mass spectra were run on a Bruker Esquire 3000 spectrometer. Thin-layer chromatography (TLC) was run on Merck silica gel 60 F-254 plates. Unless stated otherwise, starting materials used were high-grade commercial 50 products. For all tested compounds $>95 \%$ purity was confirmed by HPLC/MS using a Esquire 3000 ion-trap mass spectrometer (Bruker-Daltronics, Bremen, Germany) coupled to an Agilent HPLC system type HP 1100. A LiChroCART Supersphere100 RP-18 column ( $125 \times 2 \mathrm{~mm} ; 4 \mu \mathrm{m}$ particle size) was used, eluting 55 with $\mathrm{H}_{2} \mathrm{O}+0.1 \%$ TFA $/ \mathrm{MeOH}+0.1 \%$ TFA or Acetonitrile + $0.1 \%$ TFA. Acid $2 \mathrm{f}$ was obtained in a complex mixture with other unknown compounds, and was not possible to isolate it pure. However it could be transformed into the corresponding methyl ester $\mathbf{2 h}$

60

General method for the synthesis of amines 4a-c:

To a $100 \mathrm{ml}$ round bottomed flask, containing a stirrer bar and a reflux condenser, tin $(1.65 \mathrm{~g}, 14 \mathrm{mmol})$ and the corresponding phenol $(10 \mathrm{mmol})$ were added. Then water $(24 \mathrm{~mL})$ followed by ${ }_{65}$ concentrated hydrochloric acid $(9 \mathrm{~mL})$ were added, and the solution was heated under reflux for $1.5 \mathrm{~h}$. Then, the reaction mixture was cooled in an ice bath, a $5 \mathrm{M} \mathrm{NaOH}$ solution $(20 \mathrm{~mL})$ was added, and the aqueous solution was extracted with AcOEt $\left(3 \times 50 \mathrm{~cm}^{3}\right)$ and the combined organic extracts were washed 70 with saturated aqueous $\mathrm{NaHCO}_{3}$ and brine, dried $\left(\mathrm{MgSO}_{4}\right)$ and concentrated to dryness to give the desired amine 4

4-Amino-3-trifluoromethylphenol 4a. Yield 88\%; ${ }^{1} \mathrm{H}$ NMR $\delta_{\mathrm{H}}$ (300 MHz; DMSO) 4.88 (2H, s, NH $), 6.68-6.80$ (3H, m, ArH), $758.92(1 \mathrm{H}, \mathrm{s}, \mathrm{OH})$.

4-Amino-2-fluorophenol 4b. Yield 93\%; ${ }^{1} \mathrm{H}$ NMR $\delta_{\mathrm{H}}(300$ $\left.\mathrm{MHz} ; \mathrm{CD}_{3} \mathrm{OD}\right)$ 6.25-6.32 (1H, m, ArH), $6.40(1 \mathrm{H}, \mathrm{dd}, J$ 12.1, 2.4), $6.59(1 \mathrm{H}$, dd, $J 9.6$ and 8.6$) ;{ }^{13} \mathrm{C} \mathrm{NMR} \delta_{\mathrm{c}}(75.4 \mathrm{MHz}$, $\left.\mathrm{CD}_{3} \mathrm{OD}\right) 105.3\left(J_{\mathrm{CF}} 21 \mathrm{~Hz}\right), 112.9\left(J_{\mathrm{CF}} 3 \mathrm{~Hz}\right), 119.3\left(J_{\mathrm{CF}} 4 \mathrm{~Hz}\right)$, $80138.0\left(J_{\mathrm{CF}} 13 \mathrm{~Hz}\right), 141.6\left(J_{\mathrm{CF}} 9 \mathrm{~Hz}\right)$ and $153.4\left(J_{\mathrm{CF}} 238 \mathrm{~Hz}\right)$

4-Amino-2-methylphenol 4c. Yield $90 \%$; ${ }^{1} \mathrm{H}$ NMR $\delta_{\mathrm{H}}(300$ $\left.\mathrm{MHz} ; \mathrm{CD}_{3} \mathrm{OD}\right) 2.01\left(3 \mathrm{H}, \mathrm{s}, \mathrm{CH}_{3}\right), 6.34(1 \mathrm{H}, \mathrm{dd}, J 8.1$ and 2.3, ArH), 6.41-6.48 (2H, m, ArH); ${ }^{13} \mathrm{C}$ NMR $\delta_{\mathrm{c}}(75.4 \mathrm{MHz}, \mathrm{CD} 3 \mathrm{OD})$ $16.76,116.20,116.77,120.68,126.64,140.40$ and 149.90 .

General method for the synthesis of the TIPS-protected compounds 5a-d: 
To a solution of the corresponding phenol $(2.83 \mathrm{mmol})$ in dry DMF ( $2 \mathrm{~mL}$ ) was added a solution of triisopropylsilyl chloride $(0.655 \mathrm{~g}, 3.40 \mathrm{mmol})$ and triethylamine $(0.315 \mathrm{~g}, 3.11 \mathrm{mmol})$ in dry DMF ( $1 \mathrm{~mL})$ under $\mathrm{N}_{2}$, and the mixture was stirred at RT for 524 hours. The solution was filtered and the solvent was evaporated. The resulting residue was purified by column chromatography using hexane/AcOEt (15:1) as eluent to give the desired product.

2-(Trifluoromethyl)-4-((triisopropylsilyl)oxy)aniline 5a. Yield $1087 \%$, oil; ${ }^{1} \mathrm{H}$ NMR $\delta_{\mathrm{H}}\left(300 \mathrm{MHz} ; \mathrm{CDCl}_{3}\right) 1.08(9 \mathrm{H}, \mathrm{d}, J 7.3$, $\left.\mathrm{CH}_{3}\right), 1.12\left(9 \mathrm{H}, \mathrm{d}, J 7.3,2 \mathrm{CH}_{3}\right), 1.12-1.27(3 \mathrm{H}, \mathrm{m}, 3 \mathrm{CH}), 1.28-$ $1.45(3 \mathrm{H}, \mathrm{m}, 3 \mathrm{CH}), 2.80-3.70\left(2 \mathrm{H}\right.$, brs, $\left.\mathrm{NH}_{2}\right), 6.54(1 \mathrm{H}, \mathrm{d}, J 8.7$, $\mathrm{ArH}), 6.77(1 \mathrm{H}, \mathrm{dd}, J 8.7$ and 2.7, $\mathrm{ArH}), 6.88(1 \mathrm{H}, \mathrm{d}, J 2.7, \mathrm{ArH})$. 3-Fluoro-4-((triisopropylsilyl)oxy)aniline 5b. Yield 80\%, oil; ${ }_{15}{ }^{1} \mathrm{H}$ NMR $\delta_{\mathrm{H}}\left(300 \mathrm{MHz} ; \mathrm{CDCl}_{3}\right) 1.00\left(18 \mathrm{H}, \mathrm{d}, J 6.9,6 \mathrm{CH}_{3}\right), 1.12-$ $1.35(3 \mathrm{H}, \mathrm{m}, 3 \mathrm{CH}), 3.37\left(2 \mathrm{H}\right.$, brs, $\left.\mathrm{NH}_{2}\right), 6.20-6.25(1 \mathrm{H}, \mathrm{m}, \mathrm{ArH})$, 6.32 (1H, dd, $J 12.1,2.8, \mathrm{ArH}), 6.66$ (1H, t, $J$ 8.9, ArH).

3-Methyl-4-((triisopropylsilyl)oxy)aniline 5c. Yield 82\%, oil; ${ }^{1} \mathrm{H} \mathrm{NMR}_{\mathrm{H}}\left(300 \mathrm{MHz} ; \mathrm{CDCl}_{3}\right) 1.01\left(18 \mathrm{H}, \mathrm{d}, J 7.0,6 \mathrm{CH}_{3}\right), 1.10-$ $201.21(3 \mathrm{H}, \mathrm{m}, 3 \mathrm{CH}), 2.09\left(3 \mathrm{H}, \mathrm{s}, \mathrm{CH}_{3} \mathrm{Ar}\right), 3.10-3.40(2 \mathrm{H}$, brs, $\left.\mathrm{NH}_{2}\right), 6.29$ (1H, dd, $J$ 8.3, 2.9, ArH), $6.42(1 \mathrm{H}, \mathrm{d}, J 2.9, \mathrm{ArH})$, $6.50(1 \mathrm{H}, \mathrm{d}, J 8.3, \mathrm{ArH})$.

2-Methyl-4-((triisopropylsilyl)oxy)aniline 5d. Yield 84\%, oil; ${ }^{1} \mathrm{H} \mathrm{NMR} \delta_{\mathrm{H}}\left(300 \mathrm{MHz} ; \mathrm{CDCl}_{3}\right) 1.08\left(9 \mathrm{H}, \mathrm{d}, J 7.3,3 \mathrm{CH}_{3}\right), 1.12$ $25\left(9 \mathrm{H}, \mathrm{d}, J 7.3,3 \mathrm{CH}_{3}\right), 1.12-1.27(3 \mathrm{H}, \mathrm{m}, 3 \mathrm{CH}), 1.28-1.45(3 \mathrm{H}, \mathrm{m}$, $3 \mathrm{CH}), 2.05\left(3 \mathrm{H}, \mathrm{s}, \mathrm{CH}_{3}\right), 2.60-3.40\left(2 \mathrm{H}\right.$, brs, $\left.\mathrm{NH}_{2}\right), 6.46(1 \mathrm{H}, \mathrm{d}, J$ 8.3, ArH), 6.49 (1H, dd, $J$ 8.3, 2.6, ArH), $6.55(1 \mathrm{H}, \mathrm{d}, J 2.6$, $\mathrm{ArH})$.

\section{${ }_{30}$ General method for the synthesis of the TIPS-protected compounds $5 e$ and $5 f$ :}

To a solution of the corresponding acid $(2.35 \mathrm{mmol})$ in dry DMF $(2 \mathrm{~mL})$ was added a solution of triisoprophylsilyl chloride $(1 \mathrm{~g}$, $5.19 \mathrm{mmol})$ and triethylamine $(0.500 \mathrm{~g}, 4.95 \mathrm{mmol})$ in dry DMF 35 ( $1 \mathrm{~mL}$ ) under $\mathrm{N}_{2}$, and the mixture was stirred at RT for 24 hours. The solution was filtered and the solvent was evaporated. The resulting residue was purified by column chromatography using hexane/AcOEt (15:1) as eluent to give the desired product.

Triisopropylsilyl 2-amino-5-((triisopropylsilyl)oxy)benzoate ${ }_{40}$ 5e. Yield 94\%, oil; ${ }^{1} \mathrm{H}$ NMR $\delta_{\mathrm{H}}\left(300 \mathrm{MHz} ; \mathrm{CDCl}_{3}\right) 1.08(18 \mathrm{H}, \mathrm{d}$, $\left.J 7.3,3 \mathrm{CH}_{3}\right), 1.12\left(18 \mathrm{H}, \mathrm{d}, J 7.3,3 \mathrm{CH}_{3}\right), 1.12-1.27(3 \mathrm{H}, \mathrm{m}, 3 \mathrm{CH})$, 1.28-1.45 (3H, m, 3CH), 5.00-5.85 (2H, brs, $\left.\mathrm{NH}_{2}\right), 6.56(1 \mathrm{H}, \mathrm{d}, J$ 8.7, $\mathrm{ArH}), 6.89(1 \mathrm{H}, \mathrm{dd}, J 8.8$ and 2.9, $\mathrm{ArH}), 7.43(1 \mathrm{H}, \mathrm{d}, J 2.9$, ArH).

${ }_{45}$ Triisopropylsilyl 5-amino-2-((triisopropylsilyl)oxy)benzoate 5f. Yield $86 \%$, oil; ${ }^{1} \mathrm{H}$ NMR $\delta_{\mathrm{H}}\left(300 \mathrm{MHz} ; \mathrm{CDCl}_{3}\right) 1.00(18 \mathrm{H}, \mathrm{d}$, $\left.J 7.3,6 \mathrm{CH}_{3}\right), 1.03\left(18 \mathrm{H}, \mathrm{d}, J 7.3,3 \mathrm{CH}_{3}\right), 1.12-1.38(6 \mathrm{H}, \mathrm{m}, 6 \mathrm{CH})$, 2.55-3.00 (2H, br s, $\left.\mathrm{NH}_{2}\right), 6.56-6.67(2 \mathrm{H}, \mathrm{m}, \mathrm{ArH}), 7.02(1 \mathrm{H}, \mathrm{d}, J$ 2.1, ArH).

General method for the synthesis of azides.

To an ice cooled solution the corresponding compound 6a-f (1 g, $2.15 \mathrm{mmol})$ in $\mathrm{CH}_{3} \mathrm{CN}(5 \mathrm{~mL})$, was added dropwise $t$-BuONO $(0.332 \mathrm{~g}, 381 \mu \mathrm{L}, 3.22 \mathrm{mmol})$ followed by $\mathrm{TMSN}_{3}(0.301 \mathrm{~g}, 341$ $\left.{ }_{55} \mu \mathrm{L}, 2.57 \mathrm{mmol}\right)$ and the solution was stirred at room temperature for $4 \mathrm{~h}$. After concentrating under vacuum, the crude product was purified by silica gel chromatography (hexane) to give the desired product.

(4-Azido-3-(trifluoromethyl)phenoxy)triisopropylsilane $\quad 6$ a. 60 Yield $67 \%$, oil; ${ }^{1} \mathrm{H}$ NMR $\delta_{\mathrm{H}}\left(300 \mathrm{MHz} ; \mathrm{CDCl}_{3}\right) 1.01(18 \mathrm{H}, \mathrm{d}, J$ 7.3, $\left.\mathrm{CH}_{3} \mathrm{iPr}\right), 1.10-1.21(1 \mathrm{H}, \mathrm{m}, \mathrm{CH}$ iPr $), 7.00(1 \mathrm{H}, \mathrm{dd}, J$ 8.6, 2.6, ArH), 7.05-7.09 (2H, m, ArH).

(4-Azido-2-fluorophenoxy)triisopropylsilane 6b. Yield 71\%, oil

${ }_{65}{ }^{1} \mathrm{H}$ NMR $\delta_{\mathrm{H}}\left(300 \mathrm{MHz} ; \mathrm{CDCl}_{3}\right) 1.00\left(18 \mathrm{H}, \mathrm{d}, J 6.9,6 \mathrm{CH}_{3}\right), 1.09-$ $1.28(3 \mathrm{H}, \mathrm{m}, 3 \mathrm{CH}), 6.55-6.63(1 \mathrm{H}, \mathrm{m}, \mathrm{ArH}), 6.67(1 \mathrm{H}, \mathrm{dd}, J 11.1$ and 2.6, ArH), $6.84(1 \mathrm{H}, \mathrm{t}, J 8.9, \mathrm{ArH}) ;{ }^{13} \mathrm{C} \mathrm{NMR} \delta_{\mathrm{c}}(75.4 \mathrm{MHz}$, $\left.\mathrm{CDCl}_{3}\right) 11.6,16.7,106.6\left(J_{\mathrm{CF}} 22 \mathrm{~Hz}\right), 113.5\left(J_{\mathrm{CF}} 3 \mathrm{~Hz}\right), 121.4\left(J_{\mathrm{CF}}\right.$ $3 \mathrm{~Hz}), 132.1\left(J_{\mathrm{CF}} 9 \mathrm{~Hz}\right), 140.1\left(J_{\mathrm{CF}} 12 \mathrm{~Hz}\right) 153.2\left(J_{\mathrm{CF}} 246 \mathrm{~Hz}\right)$.

70 (4-Azido-2-methylphenoxy)triisopropylsilane 6c. Yield 64\%, oil; ${ }^{1} \mathrm{H}$ NMR $\delta_{\mathrm{H}}\left(300 \mathrm{MHz} ; \mathrm{CDCl}_{3}\right) 1.01\left(18 \mathrm{H}, \mathrm{d}, J 7.0,3 \mathrm{CH}_{3}\right)$, 1.10-1.21 (3H, m, CH), $2.15\left(3 \mathrm{H}, \mathrm{s}, \mathrm{CH}_{3}\right), 6.62(1 \mathrm{H}, \mathrm{dd}, J 8.5$, 2.8, ArH), $6.67(1 \mathrm{H}, \mathrm{dd}, J 8.5,6.7, \mathrm{ArH}), 6.72(1 \mathrm{H}, \mathrm{m}, \mathrm{ArH}) ;{ }^{13} \mathrm{C}$ $\mathrm{NMR} \delta_{\mathrm{c}}\left(75.4 \mathrm{MHz}, \mathrm{CDCl}_{3}\right) 12.99,17.08,17.99,116.96,118.82$, $75121.33,130.27,131.92,151.73$.

(4-Azido-3-methylphenoxy)triisopropylsilane 6d. Yield 70\%, oil; ${ }^{1} \mathrm{H}$ NMR $\delta_{\mathrm{H}}\left(300 \mathrm{MHz} ; \mathrm{CDCl}_{3}\right) 1.01\left(18 \mathrm{H}, \mathrm{d}, J 7.3,3 \mathrm{CH}_{3}\right)$, $1.10-1.21(3 \mathrm{H}, \mathrm{m}, 3 \mathrm{CH}), 2.08\left(3 \mathrm{H}, \mathrm{s}, \mathrm{CH}_{3}\right), 6.61(1 \mathrm{H}, \mathrm{d}, J 2.6$, $\mathrm{ArH}), 6.65(1 \mathrm{H}, \mathrm{dd}, J 8.5$ and 2.6, $\mathrm{ArH}), 6.86(1 \mathrm{H}, \mathrm{d}, J 8.5, \mathrm{ArH})$; ${ }_{80}{ }^{13} \mathrm{C}$ NMR $\delta_{\mathrm{c}}\left(75.4 \mathrm{MHz}, \mathrm{CDCl}_{3}\right) 17.95,18.31,19.31,119.74$, 121.84, 124.70, 134.20, 134.79, 154.80 .

Triisopropylsilyl 2-azido-5-((triisopropylsilyl)oxy)benzoate 6e. Yield $85 \%$, oil; ${ }^{1} \mathrm{H}$ NMR $\delta_{\mathrm{H}}\left(300 \mathrm{MHz} ; \mathrm{CDCl}_{3}\right) 1.01(18 \mathrm{H}, \mathrm{d}$, $\left.J 7.3,3 \mathrm{CH}_{3}\right), 1.05\left(18 \mathrm{H}, \mathrm{d}, J 7.3,3 \mathrm{CH}_{3}\right), 1.10-1.21(3 \mathrm{H}, \mathrm{m}, 3 \mathrm{CH})$, $851.23-1.38(3 \mathrm{H}, \mathrm{m}, 3 \mathrm{CH}), 6.99(1 \mathrm{H}, \mathrm{dd}, J 8.6,2.6, \mathrm{ArH}), 7.04(1 \mathrm{H}$, $\mathrm{d}, J$ 8.6, $\mathrm{ArH}), 7.42(1 \mathrm{H}, \mathrm{d}, J 2.6, \mathrm{ArH}) ;{ }^{13} \mathrm{C} \mathrm{NMR} \delta_{\mathrm{c}}(75.4 \mathrm{MHz}$, $\left.\mathrm{CDCl}_{3}\right) 12.0,12.6,17.80,17.82,121.2,123.11,124.1,125.2$, 133.5, 152.7, 164.1.

Triisopropylsilyl 5-azido-2-((triisopropylsilyl)oxy)benzoate 6 f. 90 Yield 70\%, oil; ${ }^{1} \mathrm{H}$ NMR $\delta_{\mathrm{H}}\left(300 \mathrm{MHz} ; \mathrm{CDCl}_{3}\right) 1.03(18 \mathrm{H}, \mathrm{d}, J$ 7.3, $\left.\mathrm{CH}_{3} \mathrm{iPr}\right), 1.06\left(18 \mathrm{H}, \mathrm{d}, J 7.3,6 \mathrm{CH}_{3}\right), 1.12-1.38(6 \mathrm{H}, \mathrm{m}$, $6 \mathrm{CH}), 6.79(1 \mathrm{H}, \mathrm{d}, J 8.7, \mathrm{ArH}), 6.90(1 \mathrm{H}, \mathrm{dd}, J 8.7$ and 2.9, $\mathrm{ArH})$, $7.38(1 \mathrm{H}, \mathrm{d}, \mathrm{J} 2.9, \mathrm{ArH}) ;{ }^{13} \mathrm{C} \mathrm{NMR} \delta_{\mathrm{c}}\left(75.4 \mathrm{MHz}, \mathrm{CDCl}_{3}\right) 12.04$, $13.13,17.88,17.98,121.76,122.06,123.24,124.62,131.86$, $95153.83,163.39$.

4-((Trimethylsilyl)ethynyl)phenol. A solution of 4-iodophenol $(0.880 \mathrm{~g}, 4 \mathrm{mmol})$, trimethylsilylacetylene $(0.855 \mathrm{~mL}, 6 \mathrm{mmol})$, $\mathrm{PdCl}_{2}(35.8 \mathrm{mg}, 0.20 \mathrm{mmol}, 5 \mathrm{~mol} \%), \mathrm{Ph}_{3} \mathrm{P}(0.106 \mathrm{~g}, 0.40 \mathrm{mmol}$, $10 \mathrm{~mol} \%$ ), CuI (19 mg, $0.10 \mathrm{mmol}, 2.5 \mathrm{~mol} \%$ ), and triethylamine $100(3.94 \mathrm{~mL}, 28.2 \mathrm{mmol})$ in of dry acetonitrile $(20 \mathrm{~mL})$ was heated at reflux under an argon atmosphere. After $3 \mathrm{~h}$ of reflux, the reaction mixture was filtered through a celite pad. The filtrate was concentrated under reduced pressure and chromatographed on silica gel using a AcOEt/hexane (1:4) as eluent to afford the 105 desired compound $(0.533 \mathrm{~g}, 70 \%)$ as a brown solid; ${ }^{1} \mathrm{H}$ NMR $\delta_{\mathrm{H}}$ $\left(300 \mathrm{MHz} ; \mathrm{CDCl}_{3}\right) 0.16\left(9 \mathrm{H}, \mathrm{s}, 3 \mathrm{CH}_{3}\right), 4.60-5.50(1 \mathrm{H}$, brs, $\mathrm{OH})$, $6.65(2 \mathrm{H}, \mathrm{d}, J 8.7, \mathrm{ArH}), 7.27(2 \mathrm{H}, \mathrm{d}, J 8.7, \mathrm{ArH}) ;{ }^{13} \mathrm{C} \mathrm{NMR} \delta_{\mathrm{c}}$ $\left(75.4 \mathrm{MHz}, \mathrm{CDCl}_{3}\right)$ 0.15, 103.68, 106.71, 114.22, 116.85, 132.78, 158.43 .

General method for the click reactions.

A solution of 4-((trimethylsilyl)lethynyl)phenol (0.1 g, 0.53 mmol) or 3-ethynylphenol $(0.063 \mathrm{~g}, 0.53 \mathrm{mmol})$ and the corresponding azide $(0.53 \mathrm{mmol})$ in DMF $(10 \mathrm{~mL})$ was treated 115 with $1 \mathrm{M}$ solution of tetrabuthylamonium fluoride in THF (see the 
amount below for each example) under argon. The reaction mixture was stirred at $0{ }^{\circ} \mathrm{C}$ for $30 \mathrm{~min}$. Then, a freshly prepared 1 $\mathrm{M}$ aqueous solution of sodium ascorbate $(0.2 \mathrm{eq})$ was added, followed by the addition of copper (II) sulfate pentahydrate $(0.1$ eq). After stirring for $24 \mathrm{~h}$ under argon atmosphere, the reaction mixture was concentrated under vacuum. Then AcOEt $(50 \mathrm{~mL})$ was added and the solution was washed with $0.1 \mathrm{M} \mathrm{HCl}$. The solvent was evaporated and the resulting residue was purified by column chromatography on silica using AcOEt/hexane as eluent, 10 to yield the desired product.

\section{4-(4-(4-Hydroxyphenyl)-1H-1,2,3-triazol-1-yl)-3-}

(trifluoromethyl)phenol 2a. From tetrabuthylamonium fluoride (1.11 mL, 1M solution in THF); chromatography eluent: AcOEt/Hexane 3:2; yield 78\%; mp 183-184 ${ }^{\circ} \mathrm{C} ; \mathrm{v}_{\max }(\mathrm{KBr}) / \mathrm{cm}^{-1}$ $153500,3037,2917,1619 ;{ }^{1} \mathrm{H}$ NMR $\delta_{\mathrm{H}}\left(300 \mathrm{MHz} ; \mathrm{CD}_{3} \mathrm{OD}\right) 5.08$ $(2 \mathrm{H}$, brs, 2OH), $6.90(2 \mathrm{H}, \mathrm{d}, J$ 8.6, ArH), $7.18(1 \mathrm{H}, \mathrm{dd}, J$ 8.6, 2.6, ArH), 7.29 (1H, d, J 2.6, ArH), $7.43(1 \mathrm{H}, \mathrm{d}, J$ 8.6, $\mathrm{ArH}), 7.72$ $(2 \mathrm{H}, \mathrm{d}, J$ 8.6, ArH $), 8.34\left(1 \mathrm{H}, \mathrm{s}\right.$, Triazole-H); ${ }^{13} \mathrm{C}$ NMR $\delta_{\mathrm{c}}(75.4$ $\left.\mathrm{MHz}, \mathrm{CD}_{3} \mathrm{OD}\right) 115.0\left(J_{\mathrm{CF}} 5 \mathrm{~Hz}\right), 116.9,120.5,122.6,124.1\left(J_{\mathrm{CF}}\right.$ $20273 \mathrm{~Hz}), 124.2,127.06,128.0,128.4,128.7\left(J_{\mathrm{CF}} 32 \mathrm{~Hz}\right), 131.9$, 135.1, 149.0, 159.2, 161.0. MS (ESI) $\mathrm{m} / z: 344.00[\mathrm{M}+\mathrm{Na}]^{+}$, $322.04[\mathrm{M}+\mathrm{H}]^{+}$

2-Fluoro-4-(4-(4-hydroxyphenyl)-1H-1,2,3-triazol-1-yl)phenol 2b. From tetrabuthylamonium fluoride $(1.11 \mathrm{~mL}, 1 \mathrm{M}$ solution in ${ }_{25} \mathrm{THF}$ ); chromatography eluent: AcOEt/Hexane 3:2; yield 76\%, mp 258-259 ${ }^{\circ} \mathrm{C} ; v_{\max }(\mathrm{KBr}) / \mathrm{cm}^{-1} 3268,3156,2917,1615 ;{ }^{1} \mathrm{H}$ NMR $\delta_{\mathrm{H}}\left(300 \mathrm{MHz} ; \mathrm{CD}_{3} \mathrm{OD}\right) 4.83(2 \mathrm{H}, \mathrm{br} \mathrm{s}, 2 \mathrm{OH}), 6.86(2 \mathrm{H}, \mathrm{d}, J$ 8.6, ArH), 7.09 (1H, t, J 8.9, ArH), 7.47-7.53 (1H, m, ArH), 7.62 $(1 \mathrm{H}, \mathrm{dd}, J 11.5$ and 2.5, ArH), $7.69(2 \mathrm{H}, \mathrm{d}, J 8.6, \mathrm{ArH}), 8.59(1 \mathrm{H}$, ${ }_{30} \mathrm{~s}$, Triazole-H); ${ }^{13} \mathrm{C}$ NMR $\delta_{\mathrm{c}}\left(75.4 \mathrm{MHz}, \mathrm{CD}_{3} \mathrm{OD}\right) 110.3\left(J_{\mathrm{CF}}\right.$ $23 \mathrm{~Hz}), 116.8,117.9\left(J_{\mathrm{CF}} 3 \mathrm{~Hz}\right), 119.3\left(J_{\mathrm{CF}} 13 \mathrm{~Hz}\right), 119.44,122.8$, $128.3,130.6,147.1\left(J_{\mathrm{CF}} 13 \mathrm{~Hz}\right), 152.8\left(J_{\mathrm{CF}} 243 \mathrm{~Hz}\right), 159.2 . \mathrm{MS}$ (ESI) $m / z: 293.98[\mathrm{M}+\mathrm{Na}]^{+}, 271.99[\mathrm{M}+\mathrm{H}]$

4-(4-(4-Hydroxyphenyl)-1H-1,2,3-triazol-1-yl)-2-

35 methylphenol 2c. From tetrabuthylamonium fluoride $(1.11 \mathrm{~mL}$, $1 \mathrm{M}$ solution in THF); chromatography eluent: AcOEt/Hexane 3:2; yield $83 \%$, mp $242-243{ }^{\circ} \mathrm{C} ; v_{\max }(\mathrm{KBr}) / \mathrm{cm}^{-1} 3335,3149$, 2917,$1612 ;{ }^{1} \mathrm{H}$ NMR $\delta_{\mathrm{H}}\left(300 \mathrm{MHz}\right.$; DMSO) $2.23\left(3 \mathrm{H}, \mathrm{s}, \mathrm{CH}_{3}\right)$, $6.86(2 \mathrm{H}, \mathrm{d}, J$ 8.0, ArH), 6.95 (1H, d, $J 8.5, \mathrm{ArH}), 7.52(1 \mathrm{H}, \mathrm{d}, J$ 40 7.9, $\mathrm{ArH}), 7.62(1 \mathrm{H}, \mathrm{s}, \mathrm{ArH}), 7.73(2 \mathrm{H}, \mathrm{d}, J 7.9, \mathrm{ArH}), 8.89(1 \mathrm{H}$, s, Triazole-H), $9.60(1 \mathrm{H}, \mathrm{s}, \mathrm{OH}), 9.82(1 \mathrm{H}, \mathrm{s}, \mathrm{OH}) ;{ }^{13} \mathrm{C} \mathrm{NMR} \delta_{\mathrm{c}}$ (75.4 MHz, DMSO) 15.9, 115.0, 115.6, 117.9, 118.7, 121.4, $122.5,125.2,126.6,128.6,147.2,155.6,157.3$. MS (ESI) $\mathrm{m} / \mathrm{z}$ : $268.00[\mathrm{M}+\mathrm{H}]^{+}$

45 4-[4-(4-Hydroxyphenyl)-1H-1,2,3-triazol-1-yl]-3-

methylphenol 2d. From tetrabuthylamonium fluoride $(1.11 \mathrm{~mL}$, $1 \mathrm{M}$ solution in THF); chromatography eluent: AcOEt/Hexane 3:2; yield $70 \%$, mp $203{ }^{\circ} \mathrm{C} ; v_{\max }(\mathrm{KBr}) / \mathrm{cm}^{-1} 3425,3186,2537$, $1612 ;{ }^{1} \mathrm{H}$ NMR $\delta_{\mathrm{H}}\left(300 \mathrm{MHz} ; \mathrm{CD}_{3} \mathrm{OD}\right) 2.10\left(3 \mathrm{H}, \mathrm{s}, \mathrm{CH}_{3}\right), 5.00$ 50 $(2 \mathrm{H}, \mathrm{br} \mathrm{s}, 2 \mathrm{OH}), 6.77-6.83(2 \mathrm{H}, \mathrm{m}, \mathrm{ArH}), 6.89(2 \mathrm{H}, \mathrm{d}, J 8.5$, ArH), 7.20 (1H, d, $J$ 8.5, ArH), $7.71(2 \mathrm{H}, \mathrm{d}, J 8.5, \mathrm{ArH}), 8.25$ $\left(1 \mathrm{H}, \mathrm{s}\right.$, Triazole-H); ${ }^{13} \mathrm{C}$ NMR $\delta_{\mathrm{c}}\left(75.4 \mathrm{MHz}, \mathrm{CD}_{3} \mathrm{OD}\right) 17.9$, $114.6,116.9,118.6,122.9,123.2,128.4,129.8,136.7,149.0$, 159.1, 160.1. MS (ESI) $m / z: 267.98[\mathrm{M}+\mathrm{H}]^{+}$

\section{${ }_{55}$ 5-Hydroxy-2-(4-(4-hydroxyphenyl)-1 H-1,2,3-triazol-1-}

yl)benzoic acid 2e. From tetrabuthylamonium fluoride $(1.65 \mathrm{~mL}$, $1 \mathrm{M}$ solution in THF); chromatography eluent: AcOEt/Hexane 5:1; yield $63 \%, 122-128{ }^{\circ} \mathrm{C} ; \mathrm{v}_{\max }(\mathrm{KBr}) / \mathrm{cm}^{-1} 3261,2925$,
1612.08; ${ }^{1} \mathrm{H}$ NMR $\delta_{\mathrm{H}}\left(300 \mathrm{MHz} ; \mathrm{CD}_{3} \mathrm{OD}\right) 5.00$ (2H, brs, OH), ${ }_{60} 6.87(2 \mathrm{H}, \mathrm{d}, J 8.4, \mathrm{ArH}), 7.08$ (1H, dd, $J 8.7$ and 3.0, $\left.\mathrm{ArH}\right), 7.38$ (2H, dd $J 8.7$ and 3.0, ArH), 7.69 (2H, d, J 8.4, ArH), 8.34 (1H, s, Triazole-H); ${ }^{13} \mathrm{C}$ NMR $\delta_{\mathrm{c}}\left(75.4 \mathrm{MHz}, \mathrm{CD}_{3} \mathrm{OD}\right) 116.8,118.2$, $119.6,123.0,123.5,128.3,128.9,129.4,148.8,159.0,160.2$, 169.4, 175.6. MS (ESI) $m / z: 297.98[\mathrm{M}+\mathrm{H}]^{+}$

${ }_{65}$ 2-Hydroxy-5-(4-(4-hydroxyphenyl)-1 H-1,2,3-triazol-1-

yl)benzoic acid 2f. From tetrabuthylamonium fluoride $(1.65 \mathrm{~mL}$, $1 \mathrm{M}$ solution in THF); chromatography eluent: AcOEt/Hexane 5:1; yield $71 \%$, mp $272-273{ }^{\circ} \mathrm{C}$ (dec.); $v_{\max }(\mathrm{KBr}) / \mathrm{cm}^{-1} 3395$, $3141,2917,2850,1675,1612 ;{ }^{1} \mathrm{H}$ NMR $\delta_{\mathrm{H}}\left(300 \mathrm{MHz} ; \mathrm{CD}_{3} \mathrm{OD}\right)$ $704.86(2 \mathrm{H}$, brs, OH), 6.89 (2H, d, $J$ 8.6, ArH), $6.99(1 \mathrm{H}, \mathrm{d}, J$ 8.7, $\mathrm{ArH}), 7.71-7.79$ (3H, m, ArH), $8.30(1 \mathrm{H}, \mathrm{d}, J 2.1, \mathrm{ArH}), 8.58$ $\left(1 \mathrm{H}, \mathrm{s}\right.$, Triazole-H); ${ }^{13} \mathrm{C}$ NMR $\delta_{\mathrm{c}}\left(75.4 \mathrm{MHz}, \mathrm{CD}_{3} \mathrm{OD}\right) 117.0$, $118.7,119.2,121.1,123.0,124.0,126.2,128.3,129.4,149.7$, 159.3, 163.63. MS (ESI) $m / z: 297.99[\mathrm{M}+\mathrm{H}]^{+}$

75 4-(4-(3-Hydroxyphenyl)-1H-1,2,3-triazol-1-yl)-3-

(trifluoromethyl)phenol 3a. From tetrabuthylamonium fluoride (0.55 mL, 1M solution in THF); chromatography eluent: AcOEt/Hexane 3:2; yield 82\%, mp $182-183^{\circ} \mathrm{C} ; v_{\max }(\mathrm{KBr}) / \mathrm{cm}^{-1}$ $3261,3194,2925,2589,1612 ;{ }^{1} \mathrm{H}$ NMR $\delta_{\mathrm{H}}\left(300 \mathrm{MHz} ; \mathrm{CD}_{3} \mathrm{OD}\right)$ $804.94(2 \mathrm{H}$, br s, 2OH), 6.80-6.84 (1H, m, ArH), $7.16(1 \mathrm{H}, \mathrm{dd}, J$ 8.6, 2.8, $\mathrm{ArH}), 7.24(1 \mathrm{H}, \mathrm{d}, J 7.8, \mathrm{ArH}), 7.29-7.37$ (3H, m, ArH), $7.44(1 \mathrm{H}, \mathrm{d}, J 8.6, \mathrm{ArH}), 8.41\left(1 \mathrm{H}, \mathrm{s}\right.$, Triazole-H); ${ }^{13} \mathrm{C}$ NMR $\delta_{\mathrm{c}}$ (75.4 MHz, $\left.\mathrm{CD}_{3} \mathrm{OD}\right) 113.7,114.9,116.7,118.2,120.5,124.1$ $\left(J_{\mathrm{CF}} 273 \mathrm{~Hz}\right), 125.3,127.0,128.7\left(J_{\mathrm{CF}} 37 \mathrm{~Hz}\right), 131.2,131.9,132.5$, ${ }_{85} 148.8,159.1,161.0$. MS (ESI) $m / z: 344.01[\mathrm{M}+\mathrm{Na}]^{+}, 322.05$ $[\mathrm{M}+\mathrm{H}]^{+}$

2-Fluoro-4-(4-(3-hydroxyphenyl)-1 $H$-1,2,3-triazol-1-yl)phenol 3b. From tetrabuthylamonium fluoride $(0.55 \mathrm{~mL}, 1 \mathrm{M}$ solution in THF); chromatography eluent: AcOEt/Hexane 3:2; yield 81\%, $90 \mathrm{mp} 225-226{ }^{\circ} \mathrm{C} ; \mathrm{v}_{\max }(\mathrm{KBr}) / \mathrm{cm}^{-1} 3305,2925,2850,1615 ;{ }^{1} \mathrm{H}$ NMR $\delta_{\mathrm{H}}\left(300 \mathrm{MHz} ; \mathrm{CD}_{3} \mathrm{OD}\right) 4.85(2 \mathrm{H}$, br s, 2OH), 6.79-6.82 $(1 \mathrm{H}, \mathrm{m}, \mathrm{ArH}), 7.09$ (1H, t, J 8.9, ArH), $7.24(1 \mathrm{H}, \mathrm{t}, J$ 7.9, $\mathrm{ArH})$, 7.31-7.35 (2H, m, ArH), 7.48-7.52 (1H, m, ArH), 7.64 (1H, dd, $J$ 11.4 and $2.5, \mathrm{ArH}), 8.64\left(1 \mathrm{H}, \mathrm{s}\right.$, Triazole-H); ${ }^{13} \mathrm{C}$ NMR $\delta_{\mathrm{c}}(75.4$ $\left.{ }_{95} \mathrm{MHz}, \mathrm{CD}_{3} \mathrm{OD}\right) 110.2\left(J_{\mathrm{CF}} 23 \mathrm{~Hz}\right), 113.6,116.6 .118 .0\left(J_{\mathrm{CF}} 4 \mathrm{~Hz}\right)$, $118.2,119.4\left(J_{\mathrm{CF}} 4 \mathrm{~Hz}\right), 120.3,130.4\left(J_{\mathrm{CF}} 8 \mathrm{~Hz}\right), 131.1,132.6$, $147.2\left(J_{\mathrm{CF}} 13 \mathrm{~Hz}\right), 149.5,152.8\left(J_{\mathrm{CF}} 243 \mathrm{~Hz}\right), 159.1$. MS (ESI) $\mathrm{m} / \mathrm{z}$ : $293.97[\mathrm{M}+\mathrm{Na}]^{+}, 271.97[\mathrm{M}+\mathrm{H}]^{+}$

4-(4-(3-Hydroxyphenyl)-1H-1,2,3-triazol-1-yl)-2-

100 methylphenol 3c. From tetrabuthylamonium fluoride $(0.55 \mathrm{~mL}$, $1 \mathrm{M}$ solution in THF); chromatography eluent: AcOEt/Hexane 3:2; yield 84\%, mp $196-197{ }^{\circ} \mathrm{C} ; v_{\max }(\mathrm{KBr}) / \mathrm{cm}^{-1} 3318,3141$, 2925, 2850, 1615; ${ }^{1} \mathrm{H}$ NMR $\delta_{\mathrm{H}}\left(300 \mathrm{MHz} ; \mathrm{CD}_{3} \mathrm{OD}\right) 2.28(3 \mathrm{H}, \mathrm{s}$, $\left.\mathrm{CH}_{3}\right), 4.83(2 \mathrm{H}$, brs, $\mathrm{OH}), 6.78-6.82(1 \mathrm{H}, \mathrm{m}, \mathrm{ArH}), 6.90(1 \mathrm{H}, \mathrm{d}, J$ 105 8.6, $\mathrm{ArH}), 7.25(1 \mathrm{H}, \mathrm{t}, J$ 7.9), 7.32-7.35 (3H, m, ArH), $7.47(1 \mathrm{H}$, $\mathrm{dd}, J 8.6$ and 2.6), $7.55(1 \mathrm{H}, \mathrm{d}, J 2.5, \mathrm{ArH}), 8.59(1 \mathrm{H}, \mathrm{s}$, Triazole$\mathrm{H}) ;{ }^{13} \mathrm{C}$ NMR $\delta_{\mathrm{c}}\left(75.4 \mathrm{MHz}, \mathrm{CD}_{3} \mathrm{OD}\right) 16.3,113.6,116.1,116.5$, $118.2,120.4,120.5,124.3,127.4,130.5,131.1,132.8,149.3$, 157.6, 159.1. MS (ESI) $m / z: 268.00[\mathrm{M}+\mathrm{H}]^{+}$

10 4-(4-(3-Hydroxyphenyl)-1H-1,2,3-triazol-1-yl)-3-

methylphenol 3d. From tetrabuthylamonium fluoride $(0.55 \mathrm{~mL}$, $1 \mathrm{M}$ solution in THF); chromatography eluent: AcOEt/Hexane 3:2; yield $80 \%$, mp $210-211{ }^{\circ} \mathrm{C} ; v_{\max }(\mathrm{KBr}) / \mathrm{cm}^{-1} 3291,2440$, $1615 ;{ }^{1} \mathrm{H}$ NMR $\delta_{\mathrm{H}}\left(300 \mathrm{MHz} ; \mathrm{CD}_{3} \mathrm{OD}\right) 2.12\left(3 \mathrm{H}, \mathrm{s}, \mathrm{CH}_{3}\right), 4.83$ $15(2 \mathrm{H}$, br s, 2OH), 6.76-6.83 (3H, m, ArH), 7.21-7.35 (4H, m, ArH), $8.35\left(1 \mathrm{H}, \mathrm{s}\right.$, Triazole-H); ${ }^{13} \mathrm{C}$ NMR $\delta_{\mathrm{c}}\left(75.4 \mathrm{MHz}, \mathrm{CD}_{3} \mathrm{OD}\right)$ 
$17.8,113.6,114.6,116.5,118.2,118.6,124.3,128.5,129.8$, $131.2,132.8,136.7,148.8,159.2,160.2$. MS (ESI) $m / z: 289.98$ $[\mathrm{M}+\mathrm{Na}]^{+}, 267.98[\mathrm{M}+\mathrm{H}]^{+}$

5-Hydroxy-2-(4-(3-hydroxyphenyl)-1H-1,2,3-triazol-1-

5 yl)benzoic acid 3e. From tetrabuthylamonium fluoride $(1.11 \mathrm{~mL}$, $1 \mathrm{M}$ solution in THF); chromatography eluent: AcOEt/Hexane 5:1; yield $71 \%, \mathrm{mp} 165-166{ }^{\circ} \mathrm{C} ; v_{\max }(\mathrm{KBr}) / \mathrm{cm}^{-1} 3313,2917$, 1705,$1589 ;{ }^{1} \mathrm{H}$ NMR $\delta_{\mathrm{H}}(300 \mathrm{MHz}$; DMSO) 6.73-6.76 $(1 \mathrm{H}, \mathrm{m}$, $\mathrm{ArH}), 7.10(1 \mathrm{H}, \mathrm{dd}, J 8.6$ and 2.8), 7.22-7.35 (4H, m, ArH), 7.44 $10(1 \mathrm{H}, \mathrm{d}, J$ 8.5, ArH), $8.77(1 \mathrm{H}, \mathrm{s}$, Triazole-H), $9.54(1 \mathrm{H}$, brs, $\mathrm{OH})$, $10.38\left(1 \mathrm{H}\right.$, brs, OH), $12.92(1 \mathrm{H}$, brs, $\mathrm{COOH}) ;{ }^{13} \mathrm{C}$ NMR $\delta_{\mathrm{c}}(75.4$ MHz, DMSO) 111.8, 114.8, 116.0, 116.6, 118.6, 123.1, 127.1, $128.3,129.7,129.8,131.8,146.0,157.7,158.3,166.1$. MS (ESI) $m / z: 297.98[\mathrm{M}+\mathrm{H}]^{+}$

2-Hydroxy-5-(4-(3-hydroxyphenyl)-1H-1,2,3-triazol-1-

yl)benzoic acid 3f. From tetrabuthylamonium fluoride $(1.11 \mathrm{~mL}$, $1 \mathrm{M}$ solution in THF); chromatography eluent: AcOEt/Hexane 5:1; yield $68 \%$, mp 243-244 ${ }^{\circ} \mathrm{C}$ with decomposition; $v_{\max }$ $20(\mathrm{KBr}) / \mathrm{cm}^{-1} 3134,2917,1675,1619 ;{ }^{1} \mathrm{H}$ NMR $\delta_{\mathrm{H}}(300 \mathrm{MHz}$; DMSO) $6.78(1 \mathrm{H}, \mathrm{d}, J$ 7.7, ArH), $7.20(1 \mathrm{H}, \mathrm{d}, J$ 8.9, $\mathrm{ArH}), 7.27$ $(1 \mathrm{H}, \mathrm{t}, J 7.9, \mathrm{ArH}), 7.34-7.39$ (2H, m, ArH), 8.07 (1H, dd, $J 8.9$ and 2.6, $\mathrm{ArH}), 8.29(1 \mathrm{H}, \mathrm{d}, J 2.6, \mathrm{ArH}), 9.23(1 \mathrm{H}, \mathrm{s}$, Triazole- $\mathrm{H})$, $9.57\left(1 \mathrm{H}\right.$, brs, OH); ${ }^{13} \mathrm{C}$ NMR $\delta_{\mathrm{c}}(75.4 \mathrm{MHz}, \mathrm{DMSO}) 112.0$, ${ }_{25} 113.9,115.1,116.2,118.5,119.5,121.5,127.2,128.5,129.9$, 131.4, 147.2, 157.7, 160.7, 170.8. MS (ESI) $\mathrm{m} / z: 297.99[\mathrm{M}+\mathrm{H}]^{+}$

General Method for the synthesis of methyl esters $2 \mathrm{~g}$,h and $3 \mathbf{h}$.

The corresponding acid (2e, $\mathbf{2 f}$, or $\mathbf{3 f})(0.17 \mathrm{mmol})$ was dissolved $30 \mathrm{in} \mathrm{MeOH}(10 \mathrm{~mL})$ and few drops of sulfuric acid were added. The reaction mixture was heated under reflux for 6 hours in argon atmosphere. Then the reaction mixture was concentrated under vacuum and the resulting residue was purified by column chromatography on silica eluting using AcOEt/DCM (3:1) as 35 eluent to yield the desired product.

Methyl 5-hydroxy-2-(4-(4-hydroxyphenyl)-1 H-1,2,3-triazol-1yl)benzoate $2 \mathrm{~g}$. Yield $73 \%$, mp $224-225{ }^{\circ} \mathrm{C} ; v_{\max }(\mathrm{KBr}) / \mathrm{cm}^{-1}$ $3373,3059,2925,1723,1686,1619 ;{ }^{1} \mathrm{H}$ NMR $\delta_{\mathrm{H}}(300 \mathrm{MHz}$; $\left.\mathrm{CD}_{3} \mathrm{OD}\right) 3.74\left(3 \mathrm{H}, \mathrm{s}, \mathrm{OCH}_{3}\right), 6.00(2 \mathrm{H}, \mathrm{brs}, \mathrm{OH}), 6.97(2 \mathrm{H}, \mathrm{d}, J$ 40 8.7, $\mathrm{ArH}), 7.21(1 \mathrm{H}, \mathrm{dd}, J 8.7$ and 2.7, $\mathrm{ArH}), 7.51(1 \mathrm{H}, \mathrm{d}, J 2.6$ $\mathrm{ArH}), 7.62(1 \mathrm{H}, \mathrm{d}, J$ 8.7, $\mathrm{ArH}), 7.74(2 \mathrm{H}, \mathrm{d}, J 8.7, \mathrm{ArH}), 9.01(1 \mathrm{H}$, s, Triazole-H); ${ }^{13} \mathrm{C}$ NMR $\delta_{\mathrm{c}}\left(75.4 \mathrm{MHz}, \mathrm{CD}_{3} \mathrm{OD}\right) 53.4,115.8$, $117.7,119.3,121.0,127.4,127.6,129.2,129.7,130.3,144.8$, 161.7, 161.9, 165.6. MS (ESI) $m / z: 312.03[\mathrm{M}+\mathrm{H}]^{+}$

45 Methyl 2-hydroxy-5-(4-(4-hydroxyphenyl)-1H-1,2,3-triazol-1yl)benzoate $2 \mathrm{~h}$ Yield $86 \%$, mp $211-213{ }^{\circ} \mathrm{C} ; v_{\max }(\mathrm{KBr}) / \mathrm{cm}^{-1}$ $3261,3141,2955,2925,1679,1619 ;{ }^{1} \mathrm{H}$ NMR $\delta_{\mathrm{H}}(300 \mathrm{MHz}$; DMSO) $3.95\left(3 \mathrm{H}, \mathrm{s}, \mathrm{CH}_{3}\right), 6.88(2 \mathrm{H}, \mathrm{d}, J$ 8.4, $\mathrm{ArH}), 7.23(1 \mathrm{H}, \mathrm{d}$, $J$ 8.4, ArH), 7.75 (2H, d, $J$ 8.6, ArH), $8.05(1 \mathrm{H}, \mathrm{dd}, J 8.9$ and 2.8 , $\left.{ }_{50} \mathrm{ArH}\right), 8.25(1 \mathrm{H}, \mathrm{d}, \mathrm{J} 2.8, \mathrm{ArH}), 9.08(1 \mathrm{H}, \mathrm{s}$, Triazole-H), 9.68 $\left(1 \mathrm{H}\right.$, br s, OH), $10.60(1 \mathrm{H}$, br s, OH $) ;{ }^{13} \mathrm{C} \mathrm{NMR} \delta_{\mathrm{c}}(75.4 \mathrm{MHz}$, DMSO) 52.6, 114.3, 115.6, 118.8, 121.2, 121.3, 126.7, 126.9, 128.8, 147.5, 157.5, 159.2, 167.8. MS (ESI) $\mathrm{m} / \mathrm{z}: 312.03[\mathrm{M}+\mathrm{H}]^{+}$

Methyl 2-hydroxy-5-(4-(3-hydroxyphenyl)-1 H-1,2,3-triazol-155 yl)benzoate $3 \mathrm{~h}$. Yield $72 \%$, mp $202-203{ }^{\circ} \mathrm{C} ; v_{\max }(\mathrm{KBr}) / \mathrm{cm}^{-1}$ $3141,2955,1671,1612 ;{ }^{1} \mathrm{H}$ NMR $\delta_{\mathrm{H}}(300 \mathrm{MHz}$; DMSO) 3.95 $\left(3 \mathrm{H}, \mathrm{s}, \mathrm{CH}_{3}\right), 6.76-6.80(1 \mathrm{H}, \mathrm{m}, \mathrm{ArH}), 7.25(2 \mathrm{H}, \mathrm{t}, J 8.9, \mathrm{ArH})$, 7.30-7.39 (2H, m, ArH), 8.07 (1H, dd, J 8.9, 2.8, ArH), $8.27(1 \mathrm{H}$, d, $J$ 2.8, ArH), $9.21(1 \mathrm{H}, \mathrm{s}$, Triazole-H), $9.59(1 \mathrm{H}$, br s, OH), ${ }_{60} 10.69(1 \mathrm{H}$, br s, OH $) ;{ }^{13} \mathrm{C}$ NMR $\delta_{\mathrm{c}}(75.4 \mathrm{MHz}, \mathrm{DMSO}) 52.6$, $112.0,114.3,115.1,116.2,118.8,119.5,121.4,127.0,128.7$, 129.9, 131.4, 147.3, 157.7, 159.2, 167.7. MS (ESI) $m / z: 312.02$ $[\mathrm{M}+\mathrm{H}]^{+}$

\section{${ }_{65}$ Computational methods.}

To perform the theoretical study of the binding mode both subtypes of ER $\alpha$ and ER $\beta$, have been taken into account. As macromolecules, several crystallographic structures of the two receptor subtypes in complex with several ligands have been 70 considered: $\mathrm{ER} \alpha$ in complex with estradiol (PDB 1A52), raloxifene (PDB 1ERR), genistein (PDB 1X7R), WAY-244 (PDB 1X7E), and 4-hydroxytamoxifen (PDB 3ERT), and ER $\beta$ in complex with genistein (PDB 1X7J), THC (PDB 1L2J), WAY202196 (PDB 1YYE), and 4-hydroxytamoxifen (PDB 2FSZ). 75 Water molecules close to the amino acids Arg394 (ER $\beta$ Arg346) and Glu353 (Glu305 ER $\beta$ ) were kept for the docking procedures. Eleven ligands (compounds $\mathbf{2 a - 2 g}$ and 3a-3f) were built using Maestro LigPrep module (www.schrodinger.com). Gaussian $03^{16}$ at $\mathrm{B} 3 \mathrm{LYP} / 3-21 \mathrm{G}^{*}$ level was used to optimize the geometries and 80 to calculate point charges. Atom types and bond types were assigned, and mol2 files were generated. Macromolecule geometries were refined by using Protein Preparation module in Maestro. The Glide module was used to perform the docking calculations. ${ }^{17,18}$ The center of the box was positioned on the 85 center of the bound ligand present in the crystallographic structure, and box size was set up to enclose the ligand binding domain. The docking procedure was performed with XP (extra precision) mode, and a van der Waals radii scale factor of 1.0/0.8 for receptor and ligand, respectively. Induced Fit Docking was 90 also used, and contained constrained minimization of the receptor with an RMSD cutoff of $0.18 \AA$, and Prime-side-chain prediction on residues within a $5 \AA$ of any ligand pose. Glide redocking was performed into structures within $30 \mathrm{kcal} \mathrm{mol}^{-1}$ of the lowest energy structure with van der Waals scaling of 1.0/0.8 for 95 receptor and ligand, respectively. The best obtained result for each ligand was considered for analysis of the ligand-receptor interactions.

\section{Biological Assays}

${ }_{100}$ Chemicals. 17- $\beta$-estradiol, crystal violet, dextran coated charcoal, PSB, Tween-20, BSA, insulin were purchased from Aldrich. Estradiol [2,4,6,7,16,17-3H(N)], scintillation counting liquid (Optifase HiSafe2) were obtained from Perkin-Elmer, Salem, MA). Estrogen receptors $\alpha$ and $\beta$ produced in insect cells 105 and sodium pyruvate were purchased from Invitrogen. Cell culture medium DMEM, FBS, antibiotics, trypsin-EDTA, amino acids, L-glutamine were purchased from Lonza. DCC-FBS was obtained from Hyclone (Erembodegem, Aalst, Belgium) and DMEM without phenol red from Gibco.

Receptor Binding Studies. The ability of the compounds to bind to ERs has been determined by competition assay according to method of Arcaro with some modifications (1). Purified fulllength human ER $\alpha$ and ER $\beta$ have been incubated for $4 \mathrm{hr}$ at $23^{\circ} \mathrm{C}$ 115 with different concentrations of compounds in the presence of 5 $\mathrm{nM}[2,4,6,7,16,17-3 \mathrm{H}]$-estradiol in total volume $150 \mu \mathrm{l}$. The stock 
of tested compounds has been prepared in DMSO. All these compounds, including [2,4,6,7,16,17-3H]-estradiol and receptors were diluted in Tween $\backslash$ PBS buffer $(99,85: 0,15 \mathrm{w} / \mathrm{v})$. A vehicle control contained $0,1 \%$ of DMSO. After incubation the non5 bound $[2,4,6,7,16,17-3 \mathrm{H}]$-estradiol has been removed by adding mixture of $10 \%$ DCC and $2 \%$ albumin bovin serum, incubating $15 \mathrm{~min}$ at $4^{\circ} \mathrm{C}$, followed by centrifugation at $6000 \mathrm{~g}$ for $5 \mathrm{~min}$ at $4^{\circ} \mathrm{C}$. $150 \mu \mathrm{l}$ of supernatant was added to $4 \mathrm{~mL}$ of scintillation liquid and the bound estradiol was measured in liquid 10 scintillation counter Beckman LS 6500 (Beckman Coulter, Inc.). Two independent experiments with three repetitions for each compound were performed. Results were expressed $\mathrm{s}$ a the percentage of specific binding of $[2,4,6,7,16,17-3 \mathrm{H}]$-estradiol to ER versus log of competitor concentration. Graph Pad Prism 15 software (non-linear regression analysis) was used to calculate the concentration needed to displace $50 \%$ of $[2,4,6,7,16,17-3 \mathrm{H}]-$ estradiol $\left(\mathrm{IC}_{50}\right)$. The values of $\mathrm{IC}_{50}$ for estradiol were 8.98 and $6.87 \mathrm{nM}$ for $\mathrm{ER} \alpha$ and $\mathrm{ER} \beta$, respectively.

Proliferation assay. MCF-7 cells were seeded in 96-well plates 20 at $5 * 10^{3}$ cells $/$ well in DMEM containing $10 \%$ FBS, $0,01 \mathrm{mg} / \mathrm{ml}$ insulin solution, $0,1 \mathrm{mM}$ nonessential amino acids. After 24 hours medium was changed for DMEM without phenol red, containing $5 \%$ dextran-coated charcoal stripped FBS (DCC-FBS), 0,1 mM nonessential amino acids, $1 \mathrm{mM}$ sodium pyruvate and $2 \mathrm{mM} \mathrm{L-}$ ${ }_{25}$ glutamine and preincubated 3 days prior to treatment. Afterwards different concentrations of assayed compounds $(1-50 \mu \mathrm{M})$ were added to cells with/without $1 \mathrm{pM}$ estradiol in order to test the capacity to induce or prevent the proliferation of MCF-7 cells. The final vehicle concentration maximally $0,1 \%$ of DMSO (and ${ }_{30} 0,1 \%$ of ethanol in case of treatment with estradiol) served as a solvent control. On day 4 medium with compounds was refreshed. On day 8 the media were removed and cells were fixed and stained with a solution containing $1 \%$ ethanol and $0.5 \%$ crystal violet. After rinsing and drying, the dye was solubilized 35 with $1 \%$ SDS and the absorbance was read at $570 \mathrm{~nm}$ (Biotec). The viability was calculated considering controls without test substance as $100 \%$ viable.

Agonist Profile. The agonistic and antagonistic activities of 40 compounds were evaluated using a commercially available cellbased assay (INDIGO Bioscience's ER Reporter Assay), which allows to quantify functional activities of the test compounds, against ER $\alpha$ and ER $\beta$. The system utilizes non-human mammalian cells engineered to provide constitutive high-level 45 expression of ER $\alpha$ and ER $\beta$. Additionally, these cells contain either ER $\alpha$ or ER $\beta$-responsive luciferase reporter gene. Thus, quantification of luciferase activity provides a surrogate measure of ER $\alpha$ and ER $\beta$ activity in the treated reporter cells. Reporter cells were dispensed in 96-well plate and then immediately dosed

\footnotetext{
${ }_{95}$ Notes

a Departamento de Química, Facultad de Farmacia, Universidad CEU San Pablo, 28668-Boadilla del Monte, Madrid, Spain.

E-mail: aramgon@ceu.es, bpaster@ceu.es; Fax: (+34)913510496; Tel: $(+34) 913724796$;

$10{ }^{b}$ Department of Organic Chemistry, Gdansk University of Technology, 11/12 G. Narutowicza St., 80-233 Gdańsk, Poland.
}

50 with the test compounds. Following overnight incubation, the treatment media were discarded and luciferase detection reagent was added. The intensity of light emission from the ensuing luciferase reaction provides a measure that is directly proportional to the level of ER activation in the reporter cells.

55 The assays were configured to perform agonist and antagonist dose-response curves. In order to obtain agonist dose-response curves ER reporter cells were treated with media alone. Estradiol was used as a positive control agonist. The $\mathrm{EC}_{50}$ values of estradiol for ER $\alpha$ and ER $\beta$ were 330 and $77 \mathrm{pM}$, respectively.

${ }_{60}$ The highest concentrations of estradiol used in order to ensure the saturating conditions were $100 \mathrm{nM}(\mathrm{ER} \alpha)$ and $4 \mathrm{nM}(\mathrm{ER} \beta)$. The final solvent control didn't exceed $0,1 \%$ of DMSO. All measurements were performed in triplicate.

\author{
${ }_{65}$ Abbreviations \\ DCM dichloromethane \\ THF tetrahydrofuran \\ DMF dimethylformamide \\ RT room temperature \\ 70 ER estrogen receptor \\ $\mathrm{CuACC}$ copper-catalyzed reaction between an azide and an \\ alkyne \\ TLC thin layer chromatography \\ TIPSCl triisopropylsilyl chloride \\ $75 \mathrm{TMSN}_{3}$ azidotrimethylsilane \\ CNS central nervous system \\ TFA trifluoroacetic acid \\ EDTA ethylenediaminetetraacetic acid \\ DCC-FBS dextran-coated charcoal-stripped fetal bovine serum
}

80

\section{Acknowledgements}

This work was supported by the Spanish Ministry of Science and Innovation (SAF2008-00945, CTQ2011-24741 and 85 AGL2012-30803) and Fundación Universitaria San Pablo CEU (USP-PC 13/10 and 15/11). We thank EADS-CASA for fellowships to K. F., M. M., J. C. and S. D.
${ }^{c}$ Department of Molecular Biology, Faculty of Mathematics and Natural Sciences, The John Paul II Catholic University of Lublin, 20-718 Lublin, Poland.

$105{ }^{d}$ Department of Environmental Biochemistry and Chemistry, Faculty of Mathematics and Natural Sciences, The John Paul II Catholic University of Lublin, 20-718 Lublin, Poland.

${ }^{e}$ Institute of Food Science, Food Technology and Nutrition (ICTAN),

Spanish National Research Council (CSIC), José Antonio Novais 10, 110 28040-Madrid, Spain. 
$\dagger$ Electronic Supplementary Information (ESI) available: NMR spectra of compounds $\mathbf{2 a - 2 h , ~ 3 a - 3 f}$ and $\mathbf{3 h}$. Predicted binding energies from the docking studies

5
Gill, B. Johnson, W. Chen, M. W. Wong, C. Gonzalez and J. A. Pople; Wallingford CT, 2004

17. R. A. Friesner, J. L. Banks, R. B. Murphy, T. A. Halgren, J. J. 75 Klicic, D. T. Mainz, M. P. Repasky, E. H. Knoll, D. E. Shaw, M. Shelley, J. K. Perry, P. Francis and P. S. Shenkin, J. Med. Chem., 2004, 47, 1739 1749 .

18. T. A. Halgren, R. B. Murphy, R. A. Friesner, H. S. Beard, L. L. Frye, W. T. Pollard and J. L. Banks, J. Med. Chem., 2004, 47, 1750801759 .

\section{References}

1. J. A. Gustafsson, J. Endocrinol., 1999, 163, 379-383.

2. R. E. Mewshaw, J. Edsall, Richard J., C. Yang, E. S. Manas, Z. B. Xu, R. A. Henderson, J. C. Keith Jr. and H. A. Harris, J. Med. Chem., 2005, 48, 3953-3979.

$20 \quad 3 . \quad$ H. A. Harris, L. M. Albert, Y. Leathurby, M. S. Malamas, R. E. Mewshaw, C. P. Miller, Y. P. Kharode, J. Marzolf, B. S. Komm, R. C. Winneker, D. E. Frail, R. A. Henderson, Y. Zhu and J. C. Keith, Endocrinology, 2003, 144, 4241-4249.

4. M. J. Meyers, J. Sun, K. E. Carlson, G. A. Marriner, B. S. 25 Katzenellenbogen and J. A. Katzenellenbogen, J. Med. Chem., 2001, 44, 4230-4251.

5. E. S. Manas, R. J. Unwalla, Z. B. Xu, M. S. Malamas, C. P. Miller, H. A. Harris, C. Hsiao, T. Akopian, W.-T. Hum, K. Malakian, S. Wolfrom, A. Bapat, R. A. Bhat, M. L. Stahl, W. S. Somers and J. C. 30 Alvarez, J. Am. Chem. Soc., 2004, 126, 15106 -15119.

6. M. De Angelis, F. Stossi, K. A. Carlson, B. S Katzenellenbogen and J. A. Katzenellenbogen, J. Med. Chem., 2005, 48, 1132-1144.

7. S. Martín-Santamaría, J. J. Rodríguez, S. de Pascual-Teresa, S. 35 Gordon, M. Bengtsson, I. Garrido-Laguna, B. Rubio-Viqueira, P. P. López-Casas, M. Hidalgo, B. de Pascual-Teresa and A. Ramos, Org. Biomol. Chem., 2008, 6, 3486-3496.

8. Spain Pat, ES P200801961; 2008.

9. J. J. Rodriguez, K. Filipiak, M. Maslyk, J. Ciepielski, S. 40 Demkowicz, S. de Pascual-Teresa, S. Martin-Santamaria, B. de PascualTeresa and A. Ramos, Org. Biomol. Chem., 2012, 10, 7334-7346.

10. G. C. Tron, T. Pirali, R. A. Billington, P. L. Canonico, G. Sorba and A. A. Genazzani, Med. Res. Rev., 2008, 28, 278-308.

11. S. K. Mamidyala and M. G. Finn, Chem. Soc. Rev., 2010, 39, 45 1252-1261.

12. T. Pirali, S. Gatti, R. Di Brisco, S. Tacchi, R. Zaninetti, E. Brunelli, A. Massarotti, G. Sorba, P. L. Canonico, L. Moro, A. A. Genazzani, G. C. Tron and R. A. Billington, Chemmedchem, 2007, 2, 437-440.

50 13. K. F. Arcaro, Y. Yang, D. D. Vakharia and J. F. Gierthy, Journal of Toxicology and Environmental Health-Part A, 2000, 59, 197210.

14. F. Minutolo, M. Macchia, B. S. Katzenellenbogen and J. A. Katzenellenbogen, Med. Res. Rev., 2011, 31, 364-442.

55 15. J. A. Katzenellenbogen, B. W. Omalley and B. S. Katzenellenbogen, Mol. Endocrinol., 1996, 10, 119-131.

16. Gaussian 03, Revision C.02, Gaussian, Inc., M. J. Frisch, G. W. Trucks, H. B. Schlegel, G. E. Scuseria, M. A. Robb, J. R. Cheeseman, J. Montgomery, J. A., T. Vreven, K. N. Kudin, J. C. Burant, J. M. Millam, ${ }_{60}$ S. S. Iyengar, J. Tomasi, V. Barone, B. Mennucci, M. Cossi, G. Scalmani, N. Rega, G. A. Petersson, H. Nakatsuji, M. Hada, M. Ehara, K. Toyota, R. Fukuda, J. Hasegawa, M. Ishida, T. Nakajima, Y. Honda, O. Kitao, H. Nakai, M. Klene, X. Li, J. E. Knox, H. P. Hratchian, J. B. Cross, V. Bakken, C. Adamo, J. Jaramillo, R. Gomperts, R. E. Stratmann, O. 65 Yazyev, A. J. Austin, R. Cammi, C. Pomelli, J. W. Ochterski, P. Y. Ayala, K. Morokuma, G. A. Voth, P. Salvador, J. J. Dannenberg, V. G. Zakrzewski, S. Dapprich, A. D. Daniels, M. C. Strain, O. Farkas, D. K. Malick, A. D. Rabuck, K. Raghavachari, J. B. Foresman, J. V. Ortiz, Q. Cui, A. G. Baboul, S. Clifford, J. Cioslowski, B. B. Stefanov, G. Liu, A. 70 Liashenko, P. Piskorz, I. Komaromi, R. L. Martin, D. J. Fox, T. Keith, M. A. Al-Laham, C. Y. Peng, A. Nanayakkara, M. Challacombe, P. M. W. 